\title{
الحسب العـدري
}

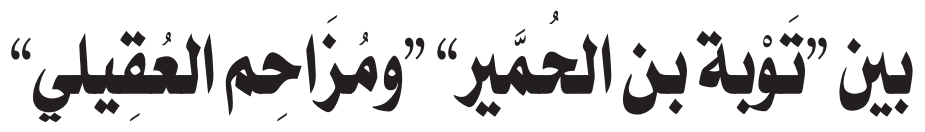

Platonic love between

"Twba bn Alhomir" and "Muzahim ALOqaili"

نجــلاءي عبد السلام محمد نصير 


$$
1 \ldots
$$




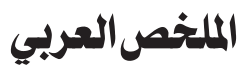

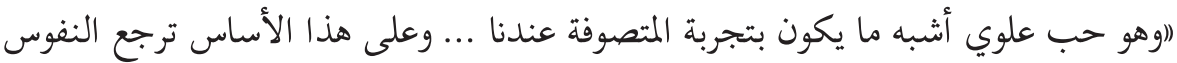

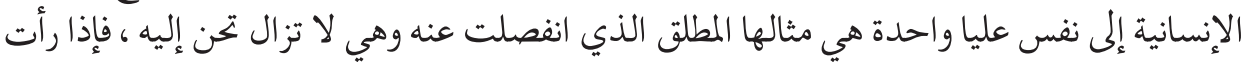

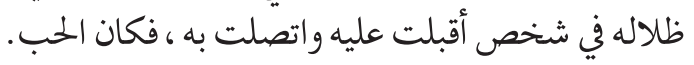

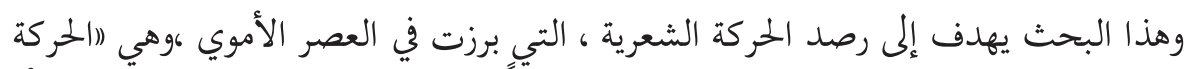

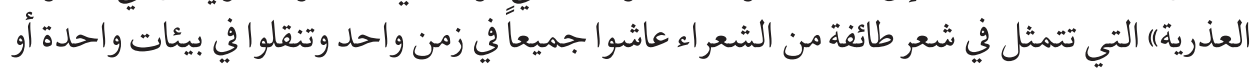
متقاربة مابين مكة والمدينة ووديان البادية الخصبة.

\section{Abstract}

This research aims to study the so-called love, platonic, which is similar to the Sufi experience we have and on this basis, the human souls return to the same high and one is the ultimate example that attracts spirits, widely followed shadows in the person agrees, when you find her soul gravitate to cling to him, be love.

Movement hair, which appeared in the Umayyad period, "the movement of virginity, which is in the poetry of a group of poets, and they all agree to live in the same time period, or in close time in environments between Mecca and Medina and Diane fertile.

\section{المقدمة}

قال اللَّيثُ عن يحيى بن سعيد عن عَمَة عن عائشة رضي الله عنها

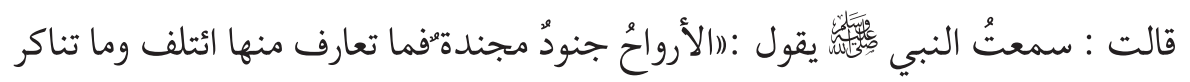
منها اختلف). (1) : مالت فالحب مشاعر إنسانية نبيلة، لا سلطان للإنسان عليها .

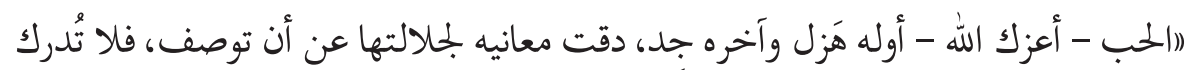

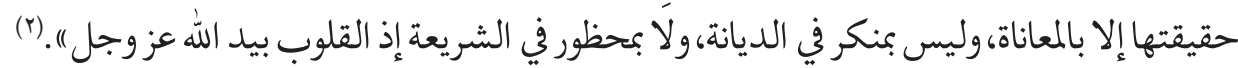

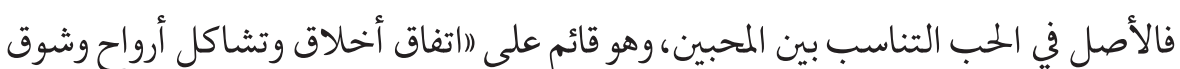

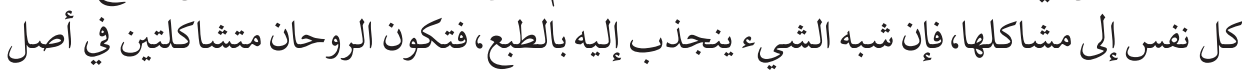

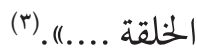

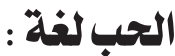

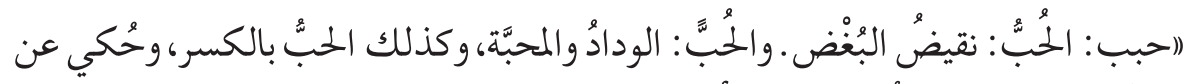

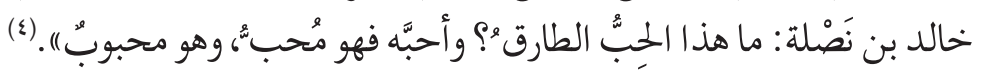




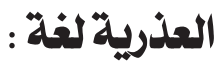

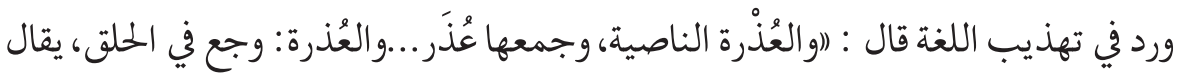

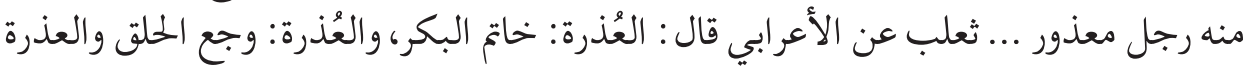

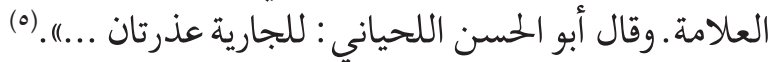

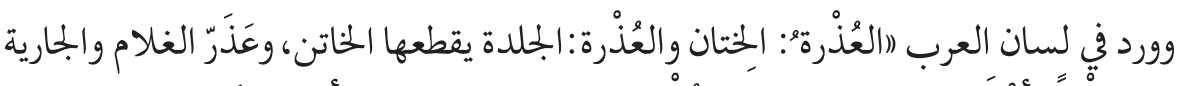

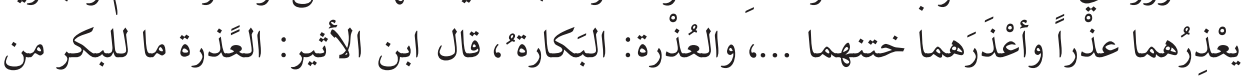

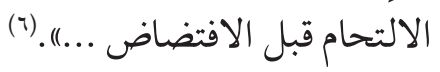

\section{العذرية اصطلاحاً}

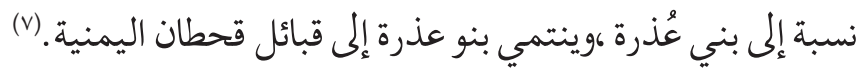

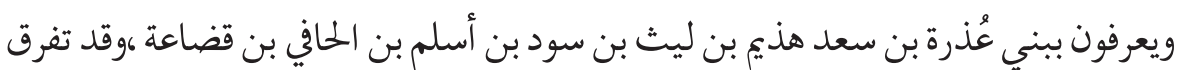

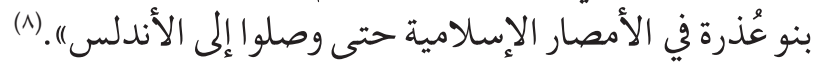

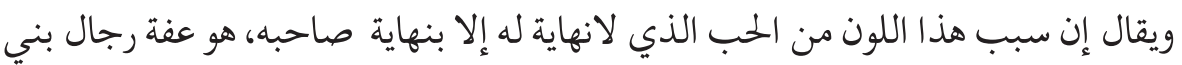

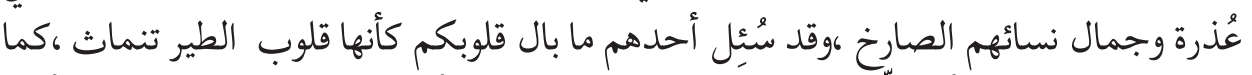

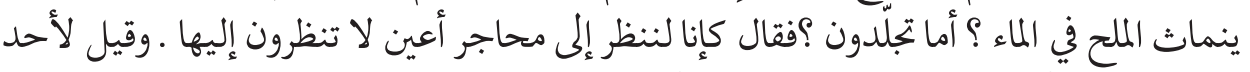

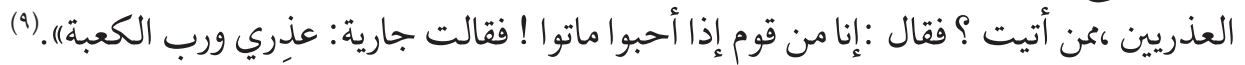

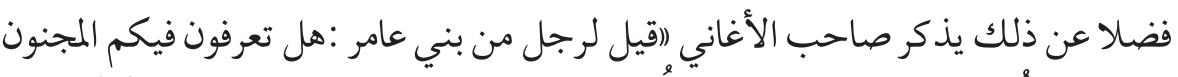

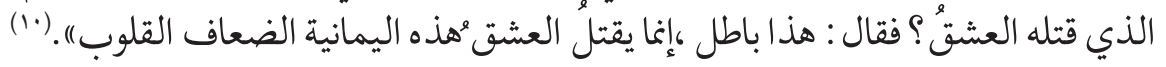

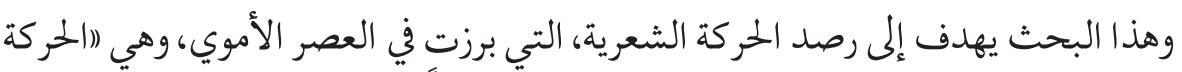

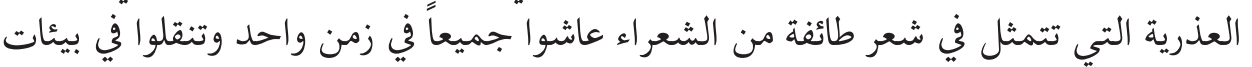

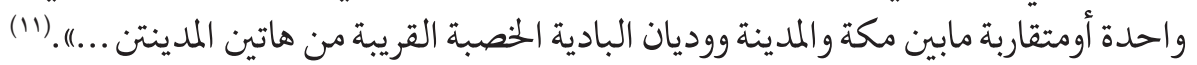

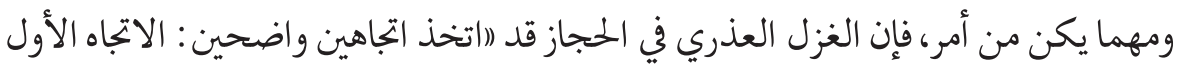

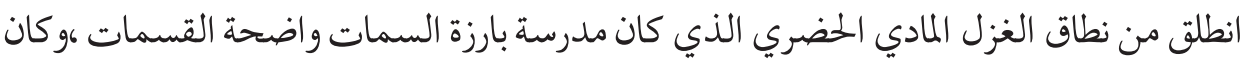

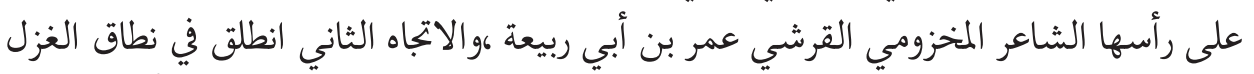

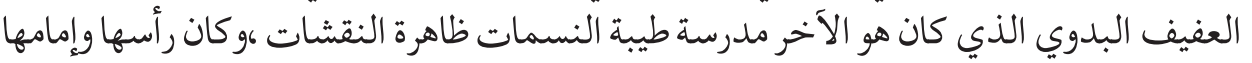

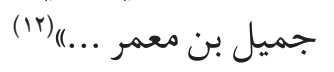

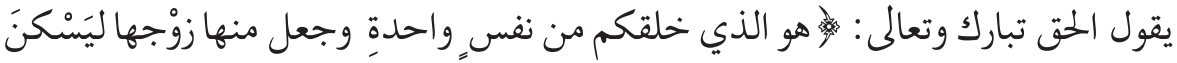


ونحن في هذا البحث ،بصدد دراسة ما يعرف بالحب الأفلاطوني اوهو حب علوي أشبه ما

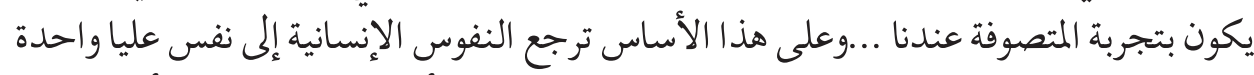

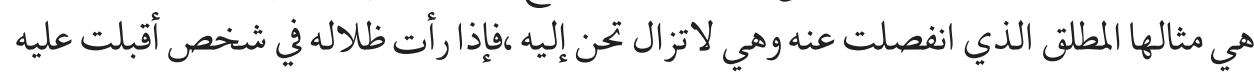
واتصلت به ،فكان الحب ....).(1)

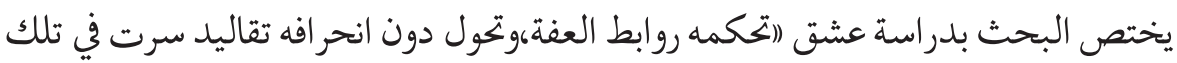

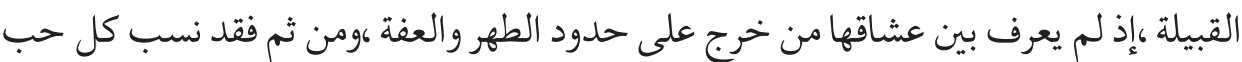
عفيف إلى بني عُذرة ،وقيل كل عشق نظيف إنه عشق عُّذري"). (10)

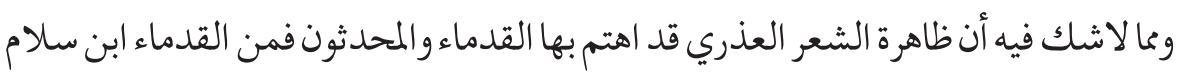

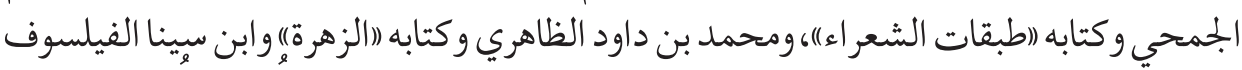

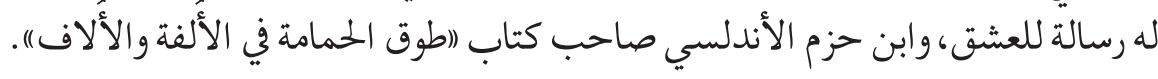

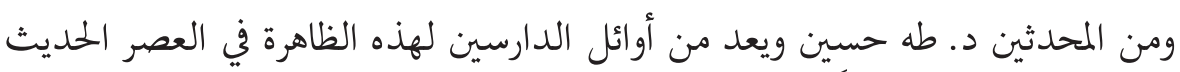

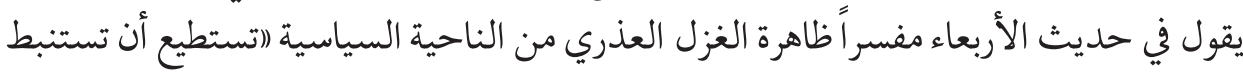

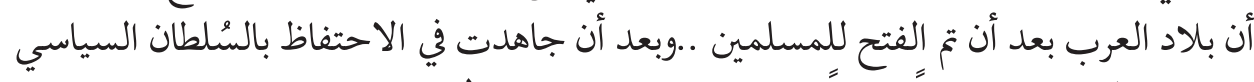

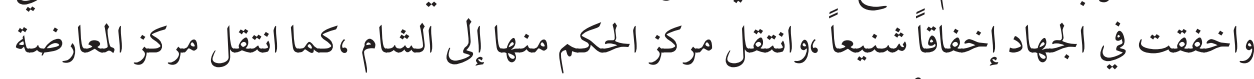

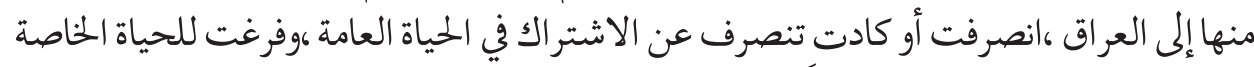

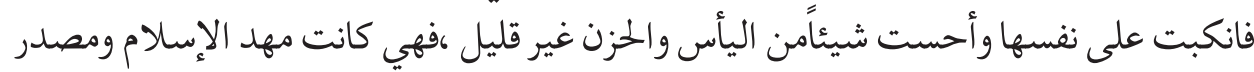

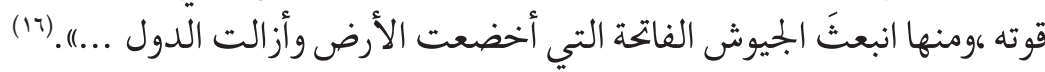

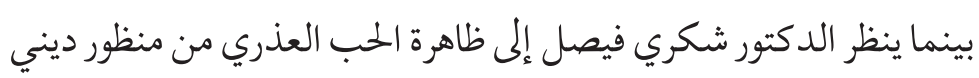

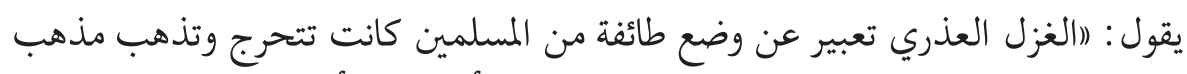

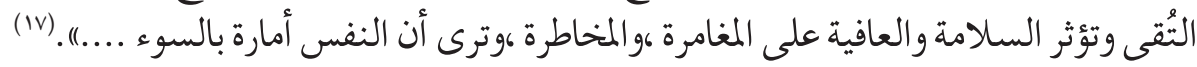

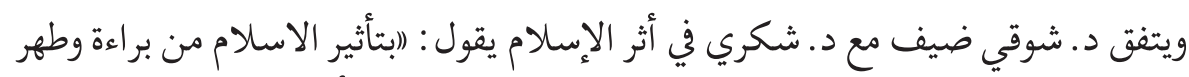

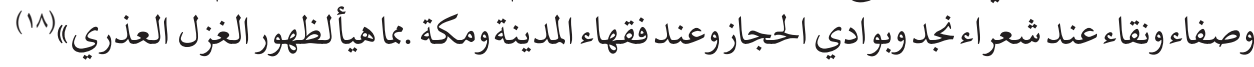

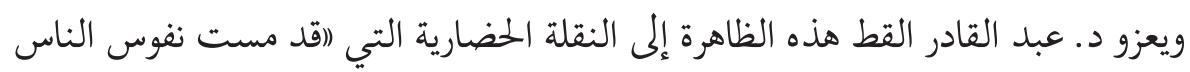

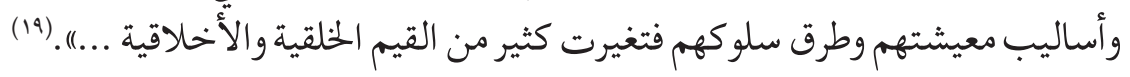

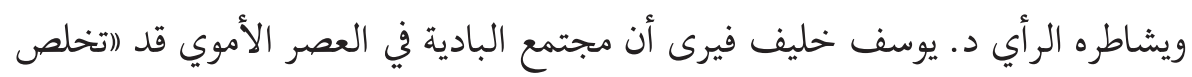

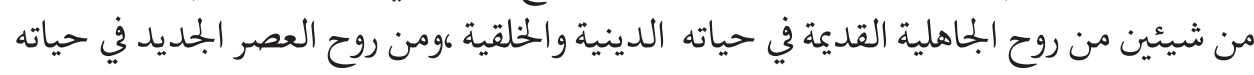

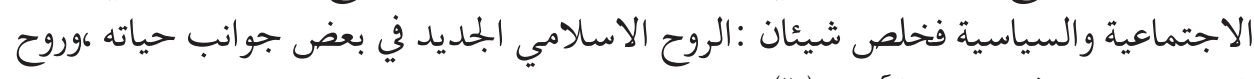
البد اوة الموروث في بعضها الآخر ).(r.) 
فضلا عن ذلك إن ظاهرة الحب العذري في العصر الأموي لم تكن بالظاهرة الغريبة (افهي

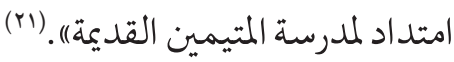

بينما يرى د. حسن عبد الله أن (بذور العذرية قد تبرعمت أو كادت قبل العصر الإسلامي

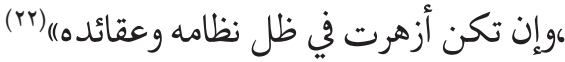
ويشاطره الرأي د. يوسف بكار ويرى أن الغزل العذري (اشاع ... في العصر الأموي وعرفته

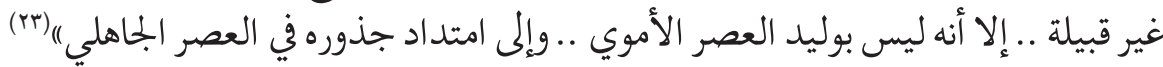

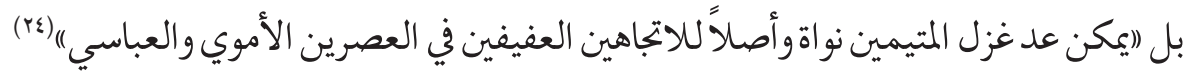

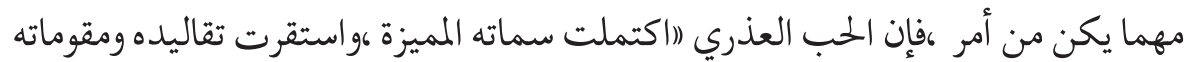

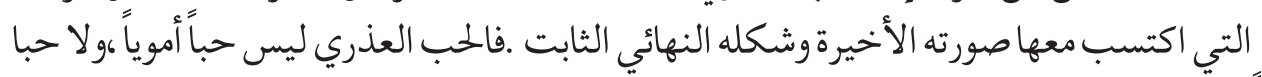

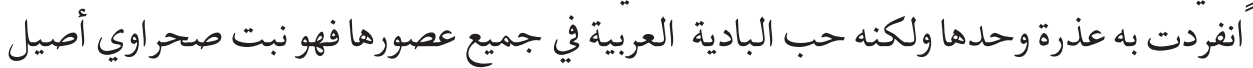

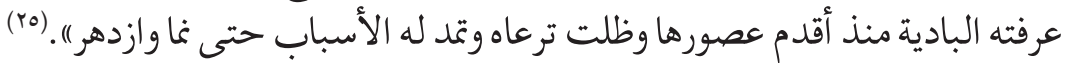

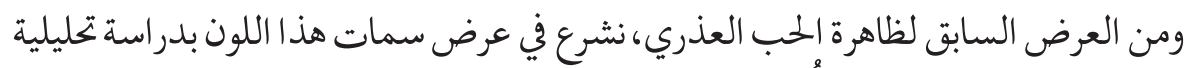

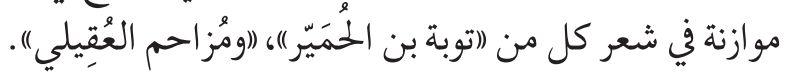

\section{توبة بن الحُميّر}

(يعد توبة من شعراء العصر الأموي ،وهو إن يكن عاش في عصر الخلفاء الر اشدين شأن ليلى

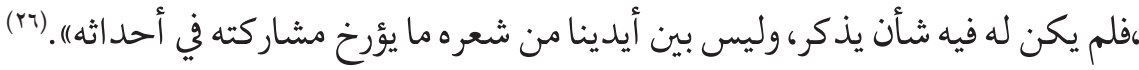

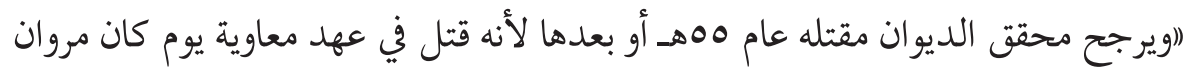

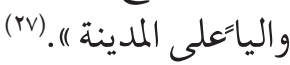

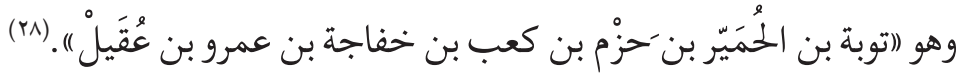

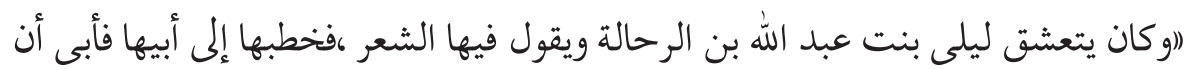

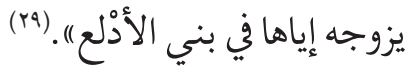
(•): وقد أنشد توبة شعر اعذريا في محبوبته ليلى كان من سماته الحرمان واللوعة والأسى يقول

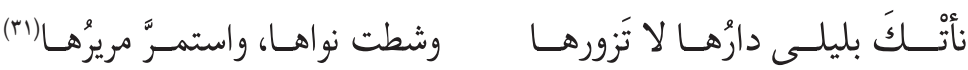

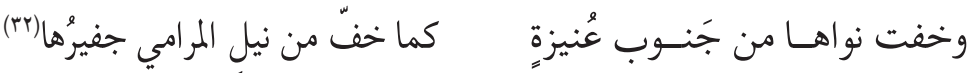
وحين كان يحاول بعض الرجال مواساته، يؤكد الشاعر أن نأيها يؤذيه يقول : 


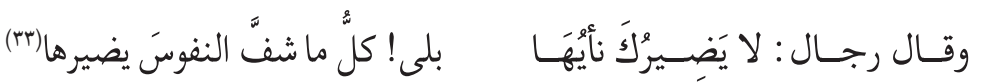

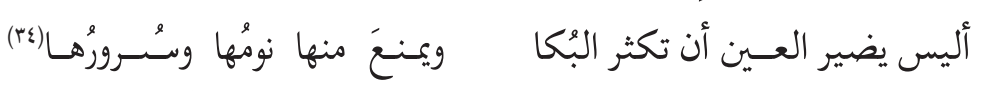

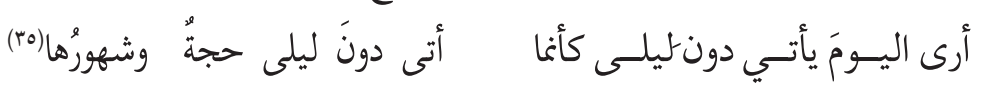

فالحياة دون ليلى ألم وأذى ويتساءل الشاعر (أليس يضير العين أن تكثر البكا) استفهام

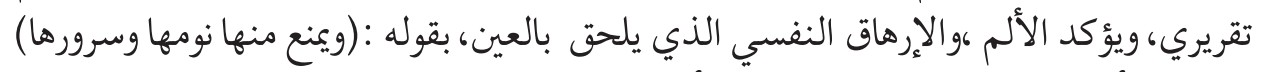

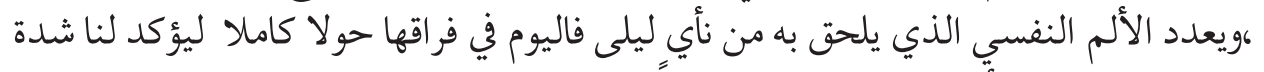

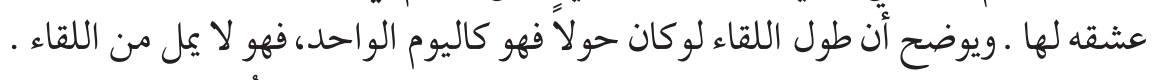

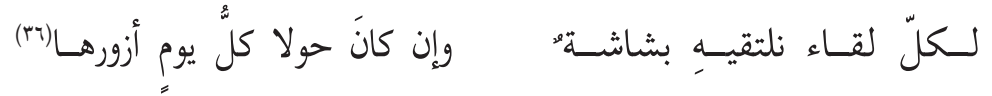

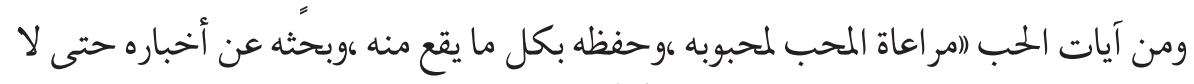
تسقط عنه رفيقة ولا جليلة ،وتتبعه لخركاته ...(IV)

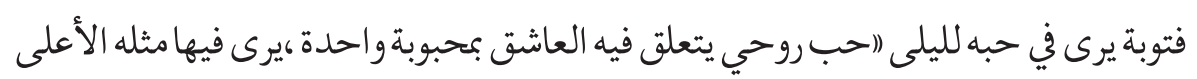

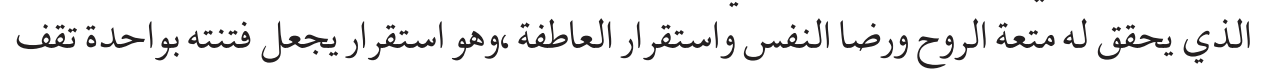

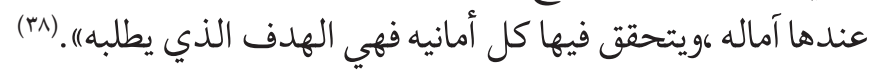
كما يشكو الشاعر مرارة الفقد والفراق، نجده يحدثناعن الرقباء والوشاة.

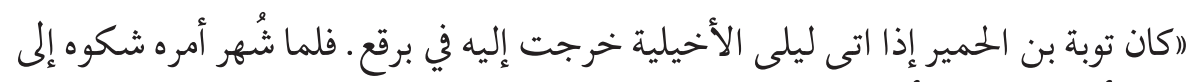

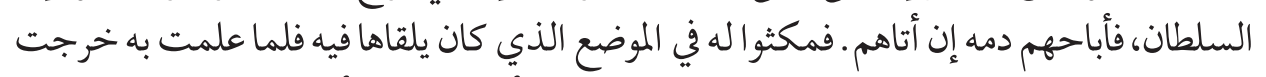

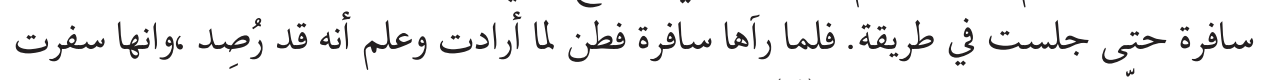

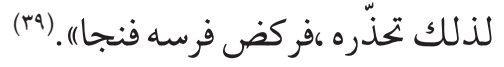
ومن ذلك قوله :

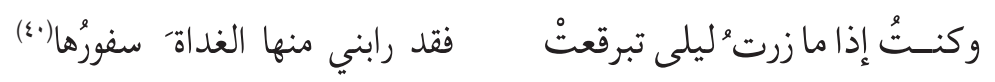

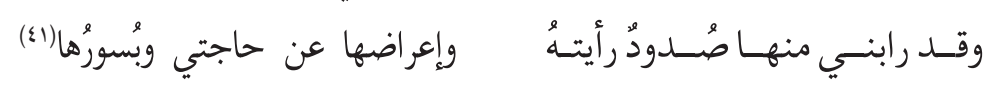

فالتبرج لم يكن سمة من سمات ليلى في اللقاء، ولكن السفور والتبرج كان بمثابة الإشارة

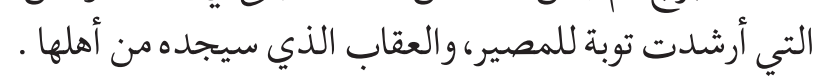

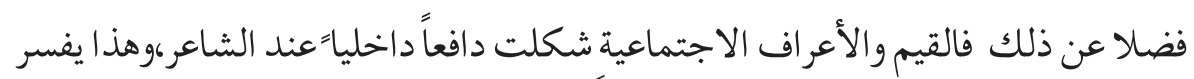

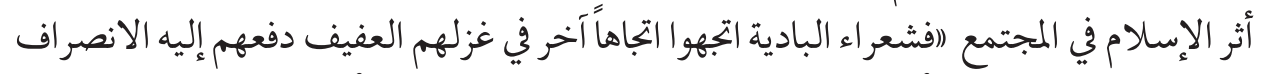

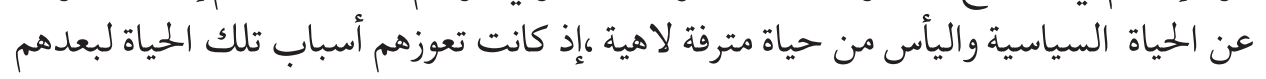

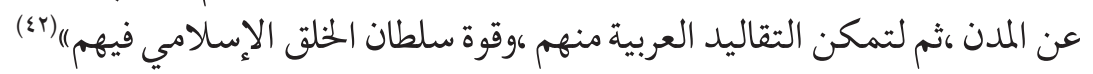


فالحب العذري اقترن باللوعة، وتمنع المحبوبة فليلى تمنعت على توبة على غير عادة. ولكنه

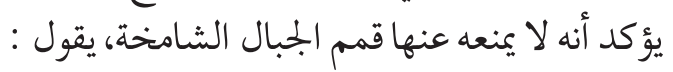

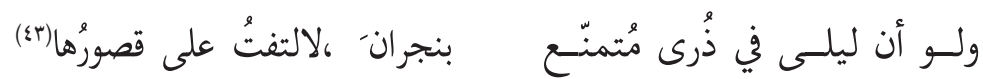

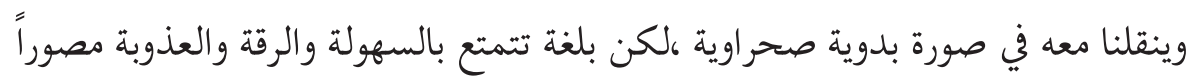
العيس وهي من كرام الايل تنقلهم نحو ليلى (نحو ديار ليلى )يقول :

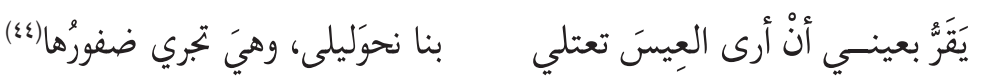

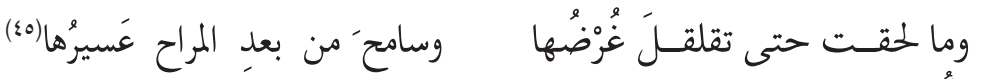

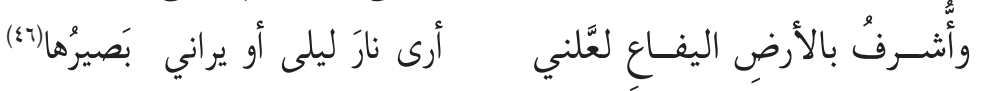

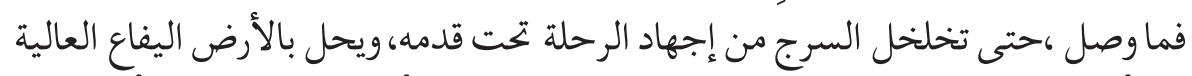

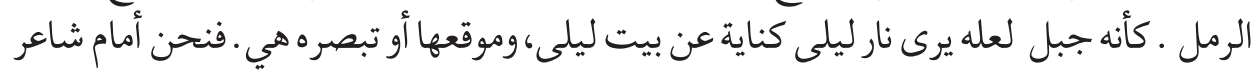

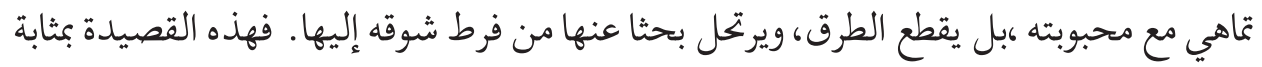

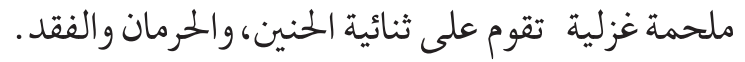

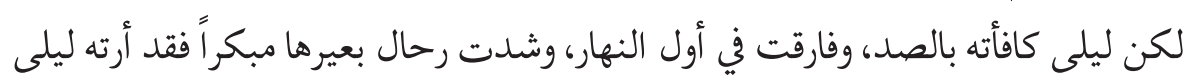

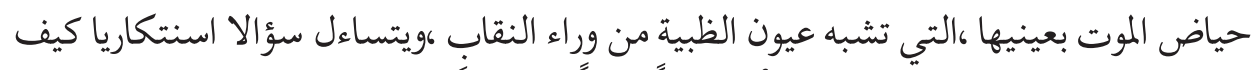

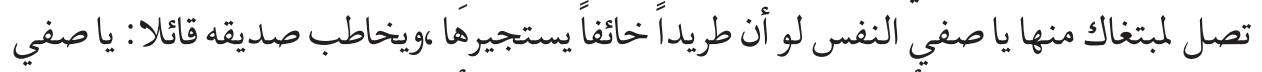

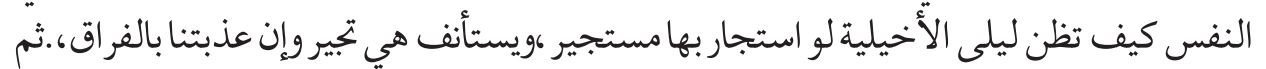

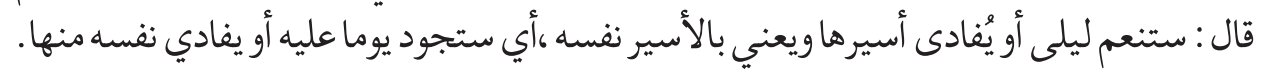

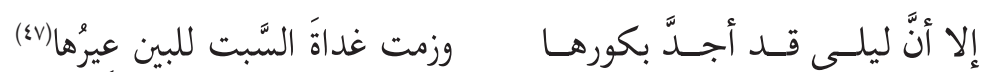

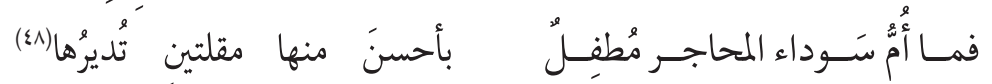

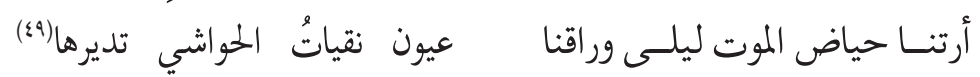

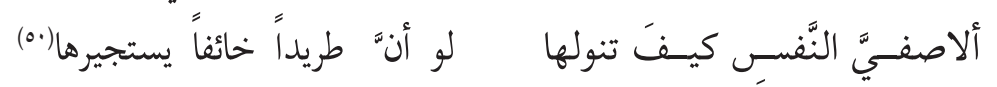

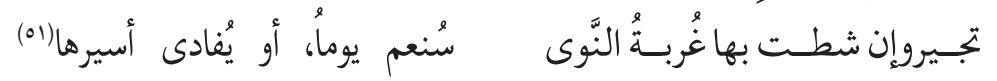
ونلاحظ هنا دقة الشاعر في تصويره لحالته النفسية، من لوعة وحزن وفقد . ومهما يكن من أمر فإن الحب العذري (اهو المظهر الفني للعواطف المتعفيفة والماتلتهبة في آن معاً

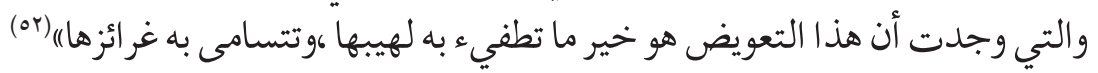
وقال توبة: (or) 


\section{تذكرتَ من ليلاكَ ما لستَ ناسياً يَذَ الدهر، إلا ريثَ ما أنت ذاكرُه

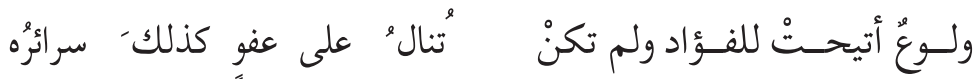

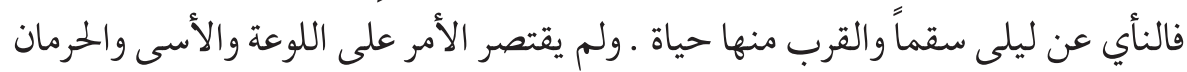

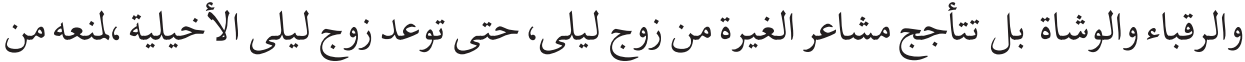

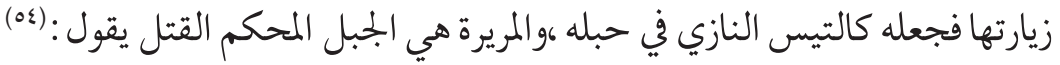

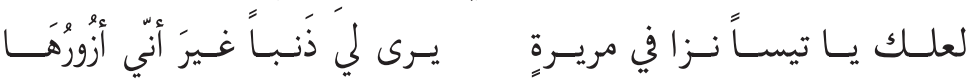

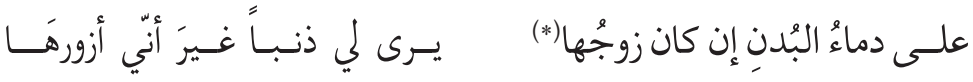

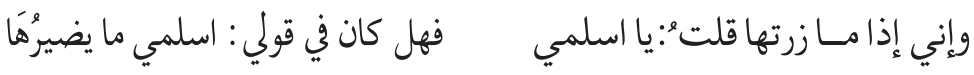

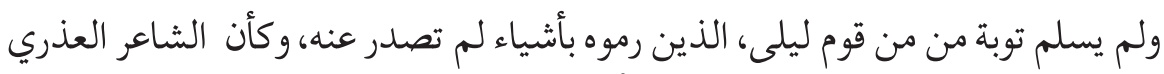

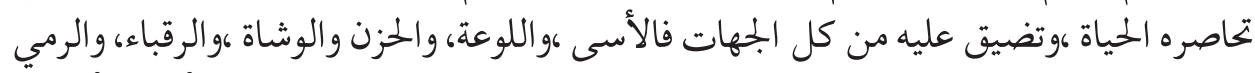

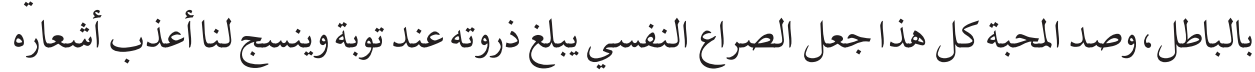
يقول:

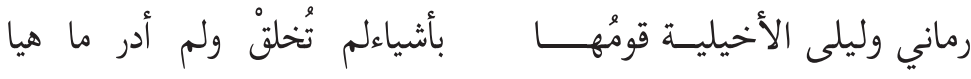

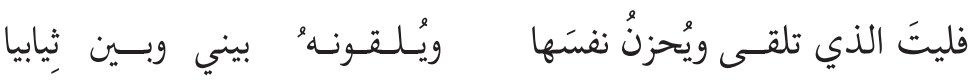

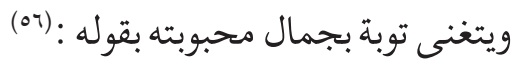

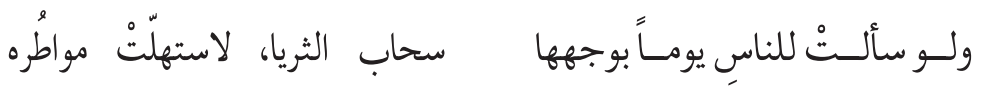

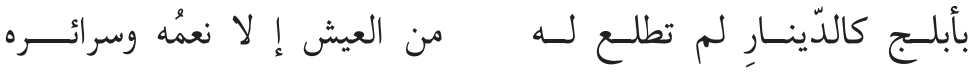

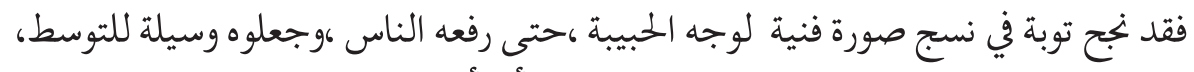

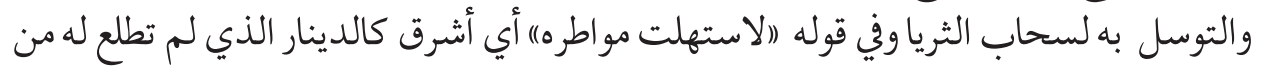

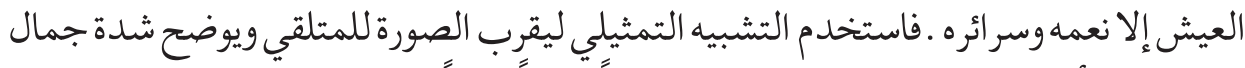
وجه ليلى الأخيلية فهذ التشبيه العذب جاء التباء عفوياً سلساً بعيداً العن التقعير والتعقيد.

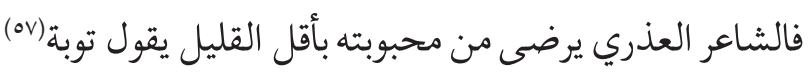

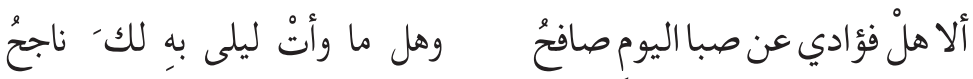

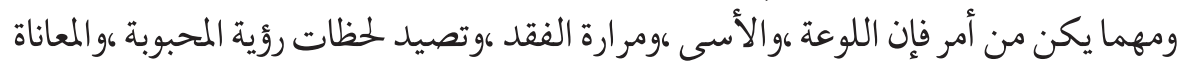

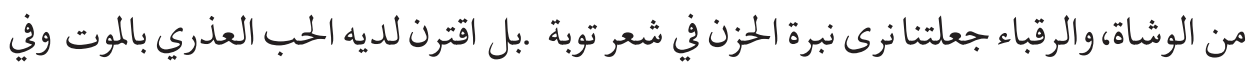

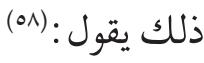




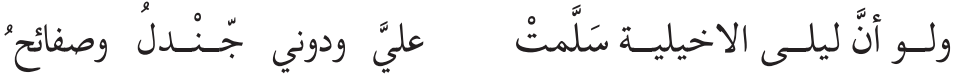

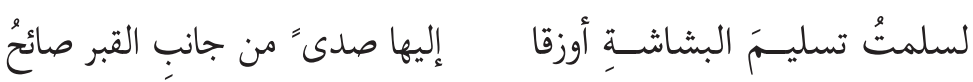 \\ فحب ليلى اقترن عنده بالموت ،ونجد توبة يستدعي الطلل المعنوي النفسي.}

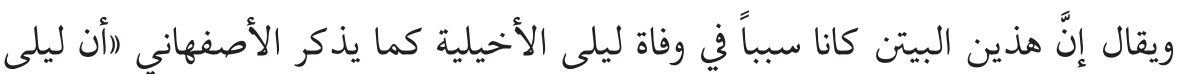

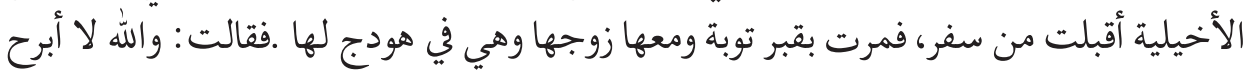

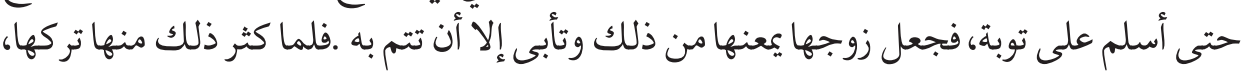

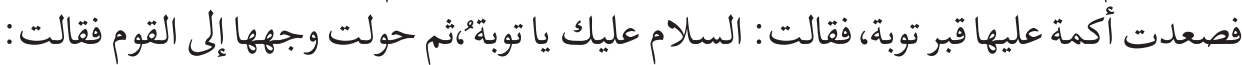

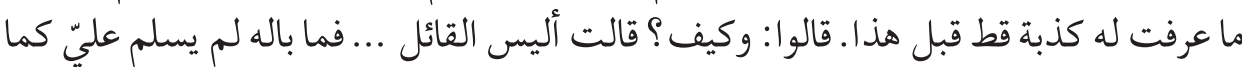

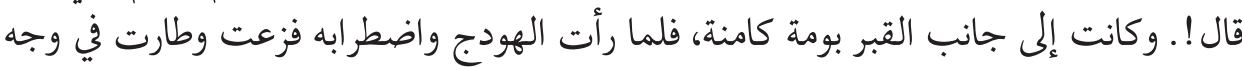

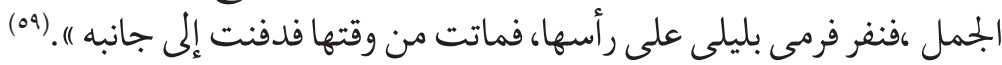

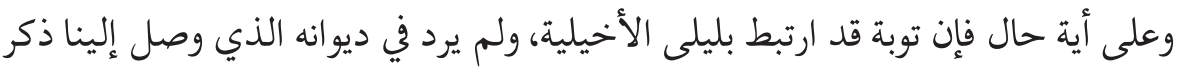

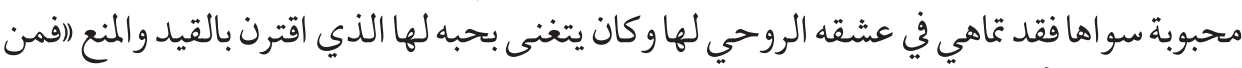

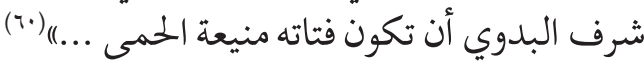

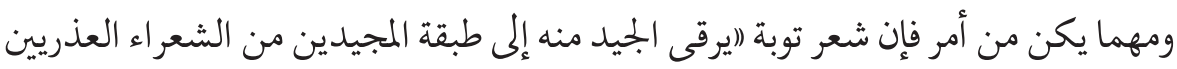

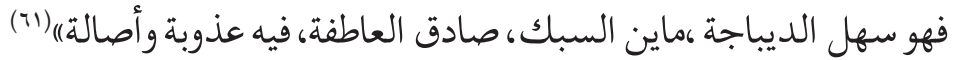
وسنعرض لأنموذج آخر للغزل العذري تعدد فيه اسم المحبوبة بين مية ،وليلى وصفراء

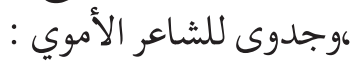

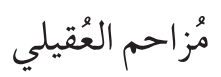

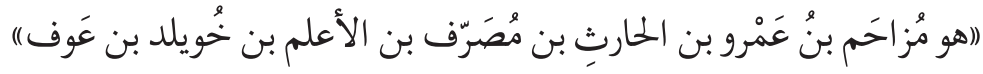$$
\text { ابن هوزان }
$$

وقيل مُز احم بنُ عَمرو بن مُرَّة بن الحارث بن مُصَرِف بن الأعلم ،وهذا القول عندي أقرب

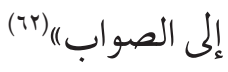

((وصفه أبو عبيدة بأنه رجل عَزْل يكتفي بذاته عن حمل السلاح لشجاعته)|(Tr) وهو شاعر (لوي

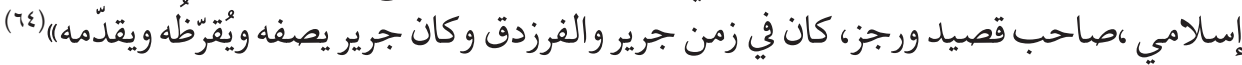
فُمْزاحم شاعر رقيق، يقول الشعر الغزل، وينتقي العبارة المناسبة ،ويحكم التعبير عنه إحكاماً

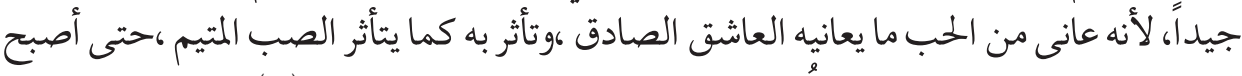

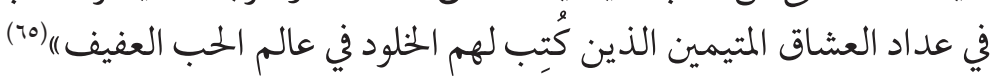




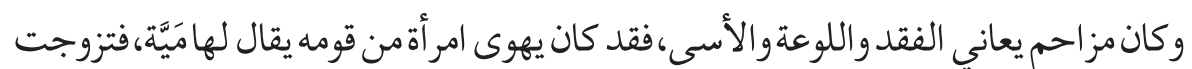

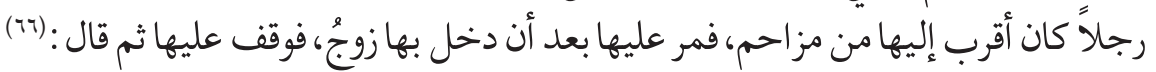

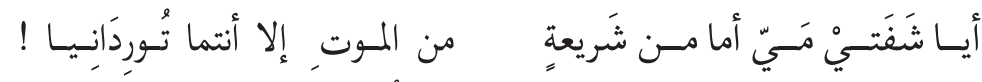

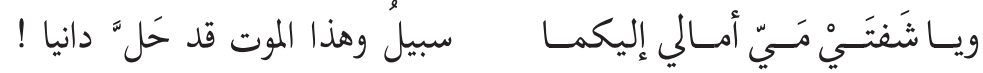

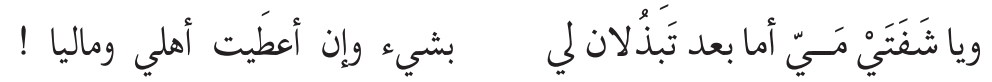

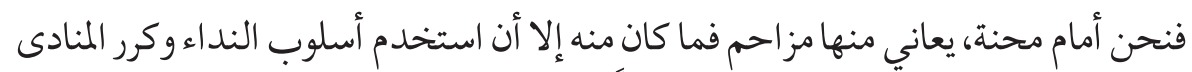

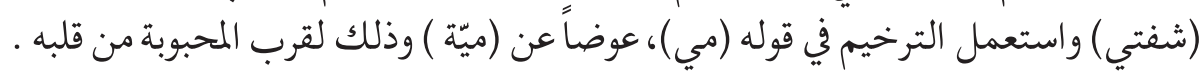

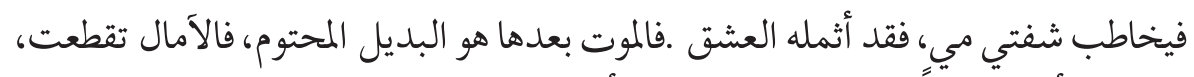

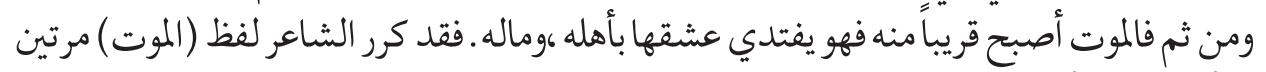

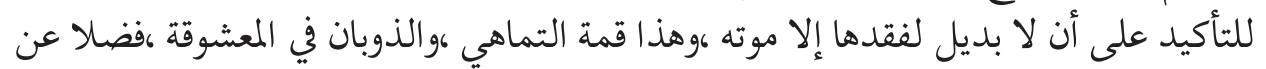

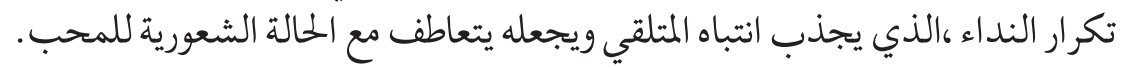

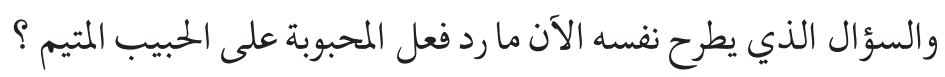

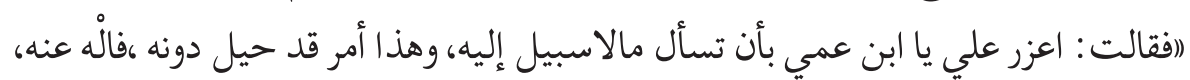
فانصرف. (IV) فتقاليد المجتمع انتصرت على الحب ،وتزوجت المحبوبة من غيره فضلاًعن ذلك كان كان ردها

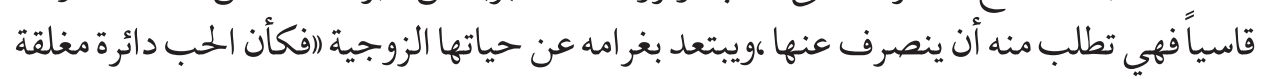

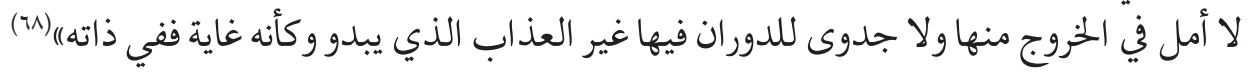
فقد ناجى مزاحم شفة ليلى (اوليس معنى ذلك أنه حب يلغي الجسد إلغاءً تاماً،فإن هذا

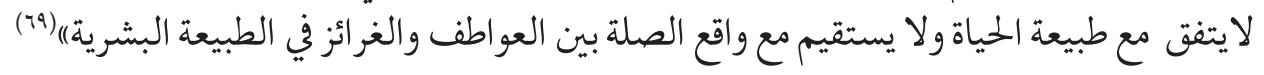

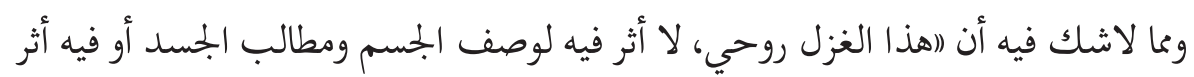

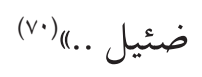

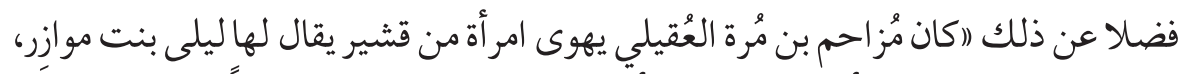

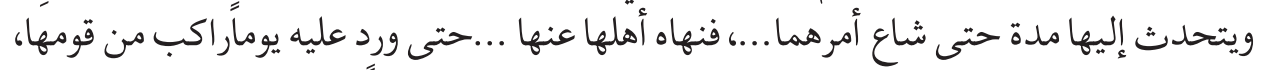

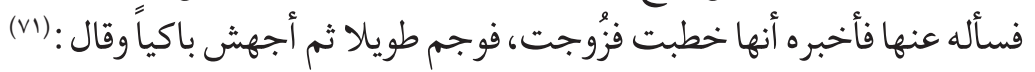

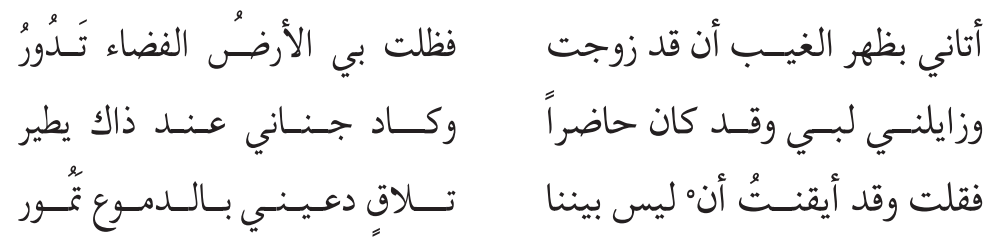




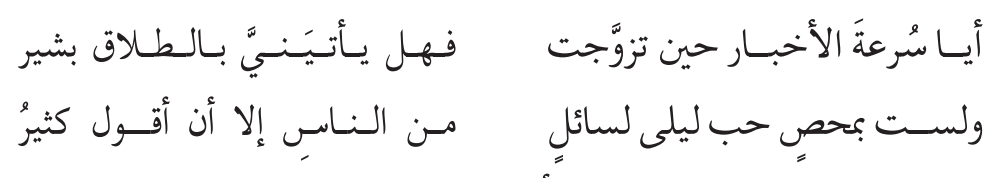

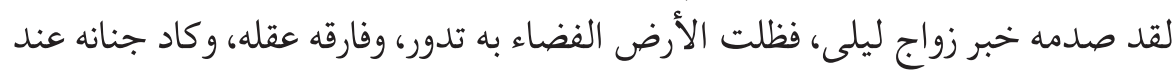

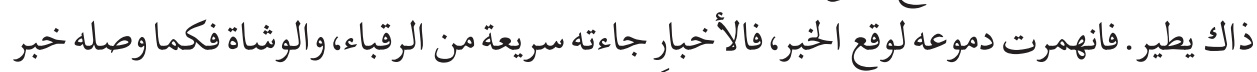

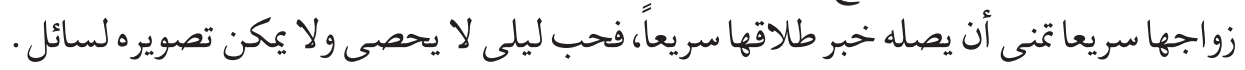

$$
\text { فنحن أمام شاعر متيم عشت محبوبته وفجعه خبر زواجها فسلبه لبه. }
$$

فضلا عن ذلك جاءت لغته سهلة ،بعيدة عن الحوشي، والغريب ،وبلوحة فنية رائعة صور لنا دور ان الأرض تحت أقدامه وكيف طار عقله.

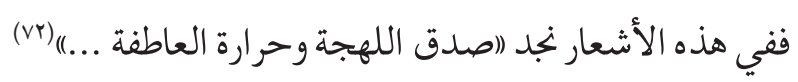

$$
\text { قال مُز احم للمجنون مُهن }
$$

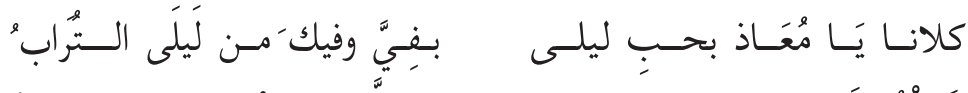

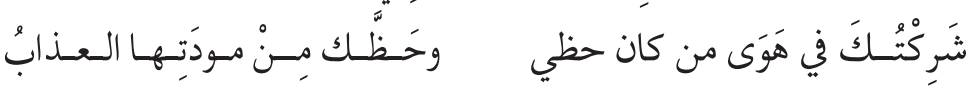

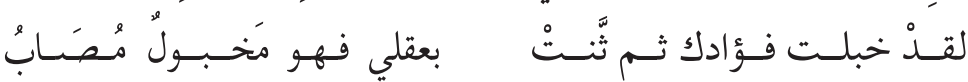

فمز احم يشاطر معاذ حب ليلى فالقاسم المشترك بينهما ( العذاب) فقد أفقد حب ليلى معاذ عقله ثم ثنت بعقل مزاحم ،فهذه المحبوبة سلبت محبيها عقولهم .فهناك رواية في الأغاني (قال

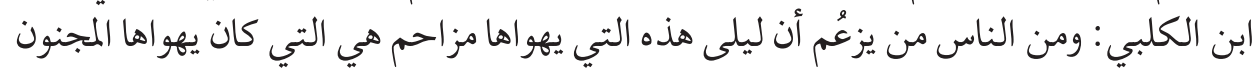

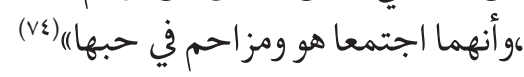

هذا يؤكد لنا على صدق العاطفة فالشاعر العذري الذي عزلته العادات والتقاليد، وتزوجت

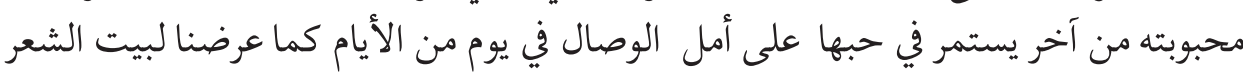

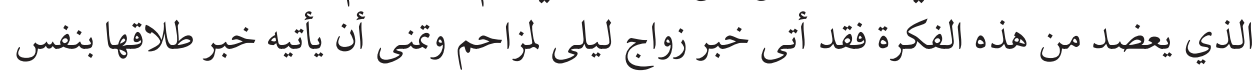

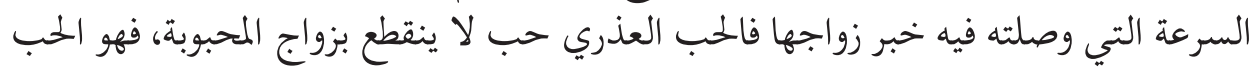

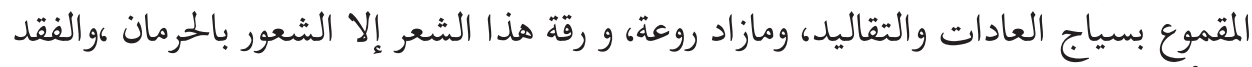
كوالأسى مما جعل الثاعر يبث في مقطوعاته الغزلية وقصائده دفقات حبه التي تصل للمتلقي بسهولة، و رقة ،وعذوبة تجعله يتماهي مع الشاعر ويتعاطف معهد.

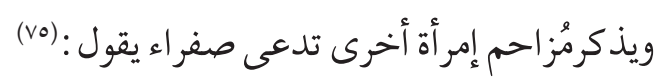

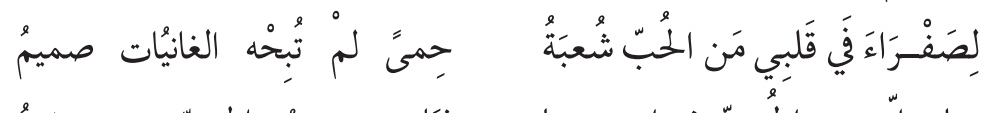

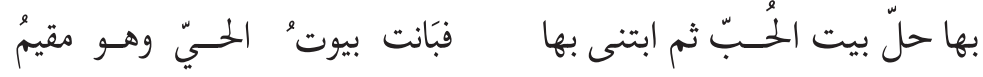


إذ يحن الشاعر إلى حبيبته صفراء، التي ملكت قلبه فحبه لصفراء هو البيت الذي مازال

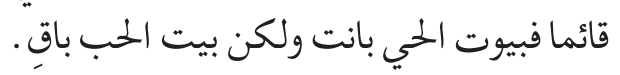

فهذه اللوحة الفنية الرائعة التي صورها الشاعر من خلال الاستعارة المكنية الحب بناء يبنى.

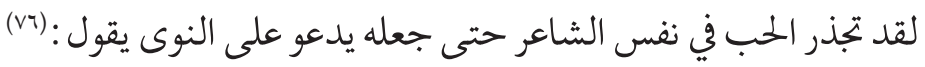

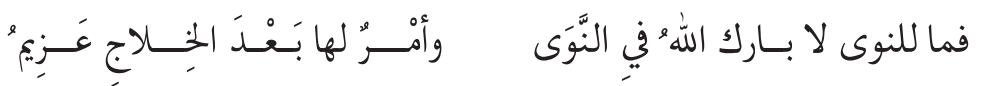

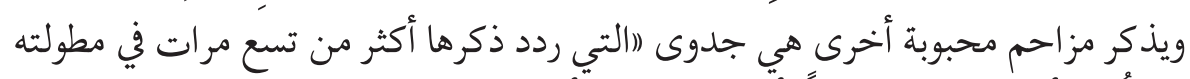

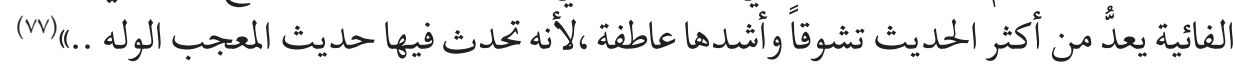
(v)): يقول

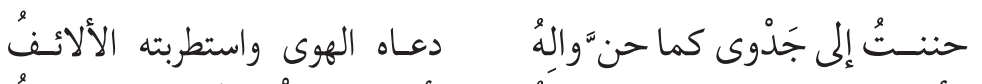

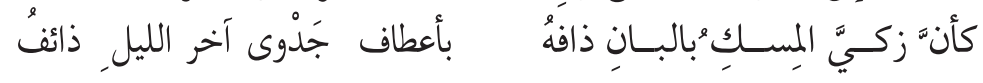

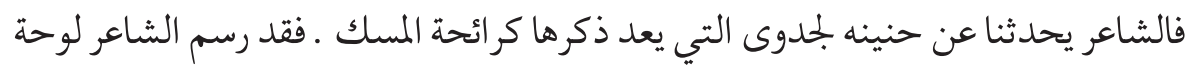

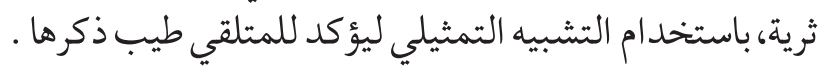

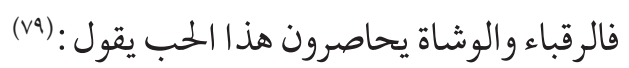

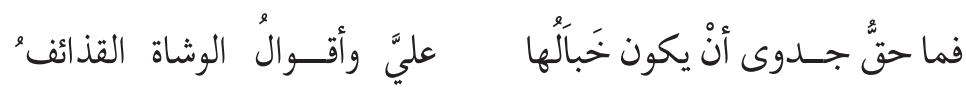
فحب جدوى أورثه خبالا، وزادته أقوال الوشاة وبالاً

$$
\text { ويقول: (^) }
$$$$
\text { وما بَرِحِح الواشون حتسى ارتموا بنا وحتى قلوبُ عن قلوبٍ صوارِفُ }
$$

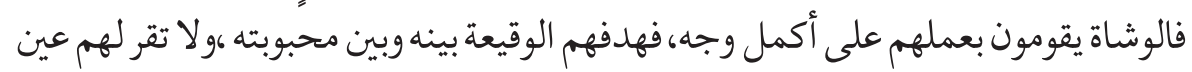
إلا بذلك.

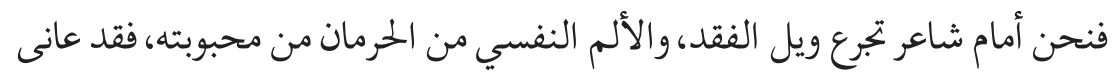

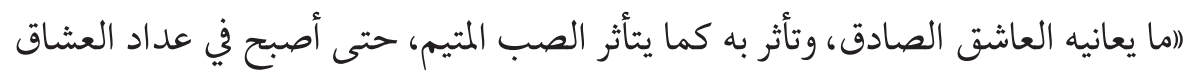

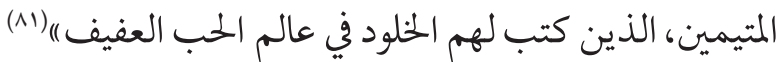

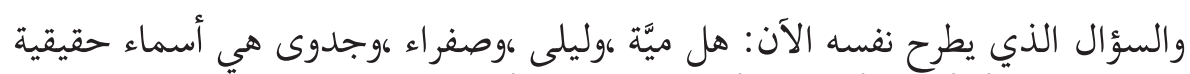

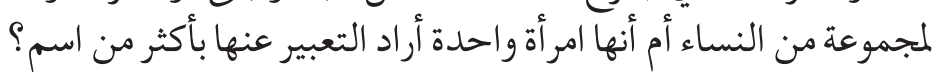

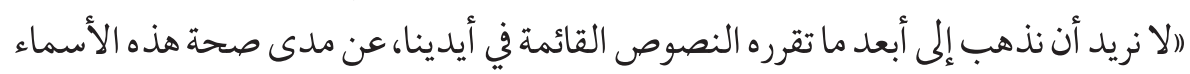

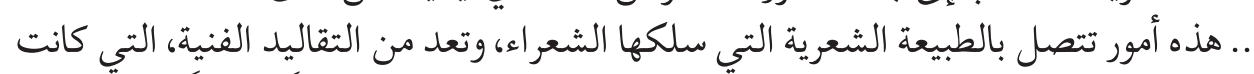

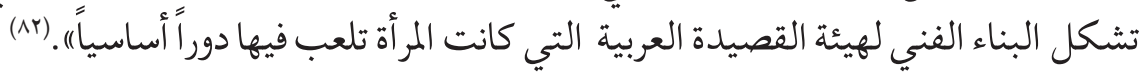


ومهما يكن من أمر فإنَ الرقابة التي كانت تفرضها القيم الاجتماعية لعبت دوراً أساسيا في

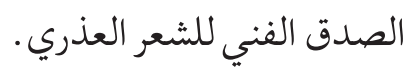

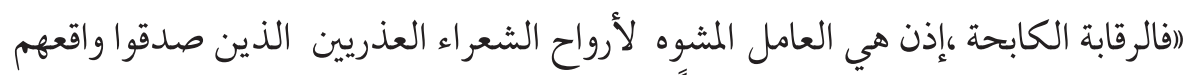

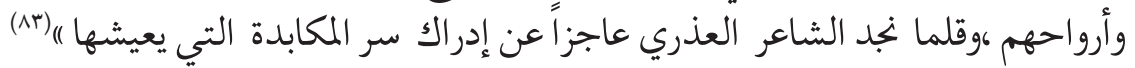

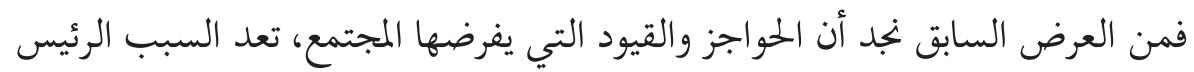

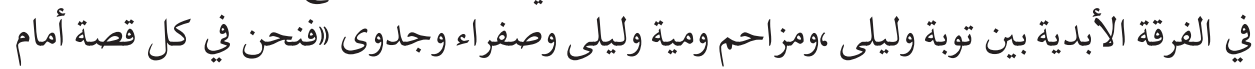

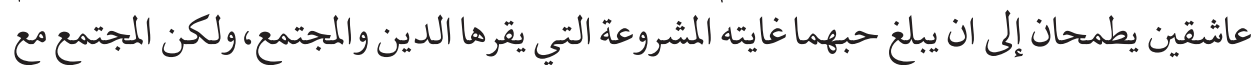

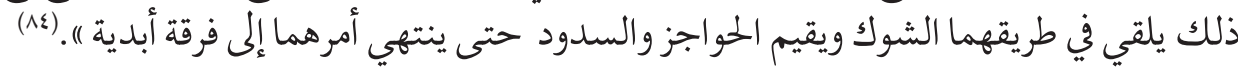

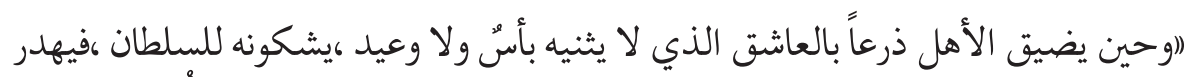

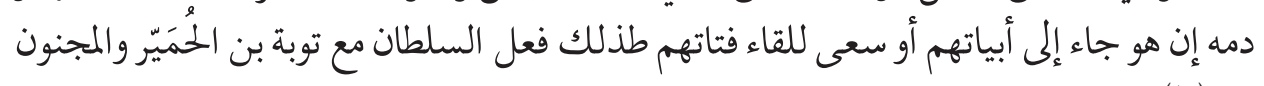
${ }^{(\wedge \circ)}(1 \ldots$

\section{ثانيا الظواهر الإسلوبية والفنية}

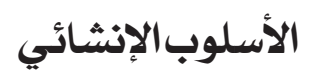

(اقسم البلاغيون الإنشاء إلى قسمين : طلبي وغير طلبي ،وقصدوا بالإنشاء الطلبي مايلزم

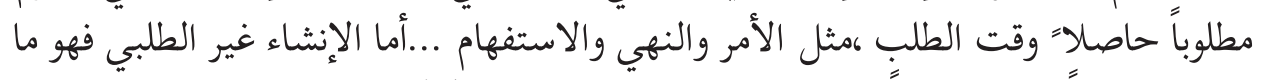

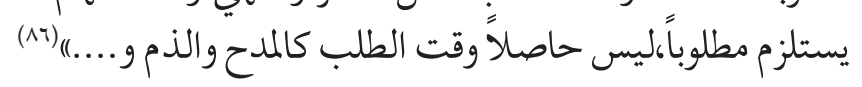

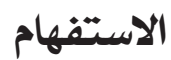

وهو (اطلب حصول صورة الشيء في الذهن بأدوات مخصوصة كالهمزة ونحوهاواوالألفاظ

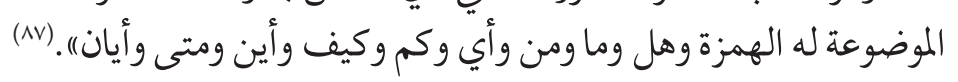

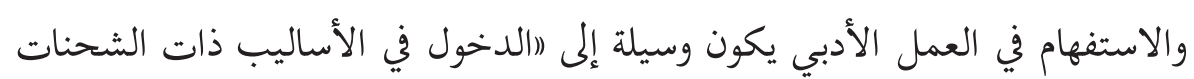

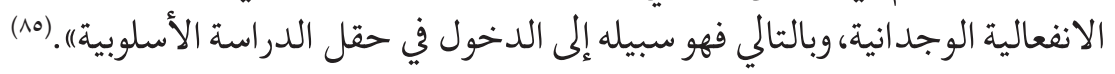

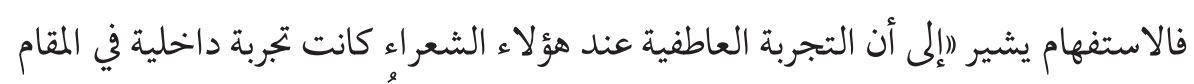

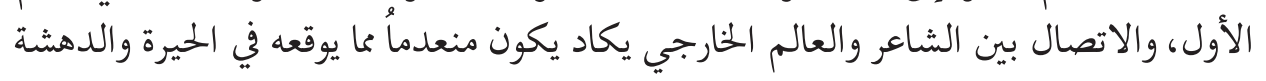

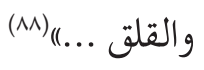

فمن الاستفهام بغرض التقرير قول توبة : في 


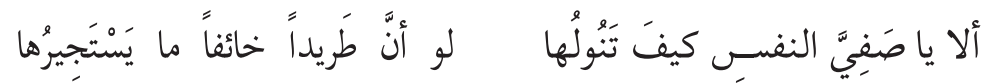

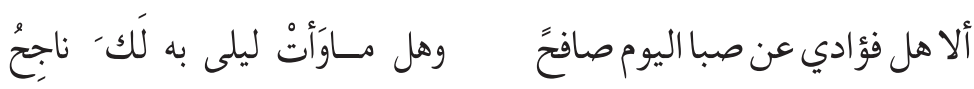

$$
\text { ومنه قول مزاحم (91) }
$$

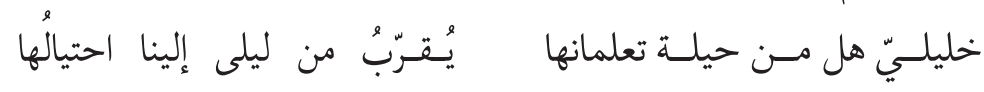

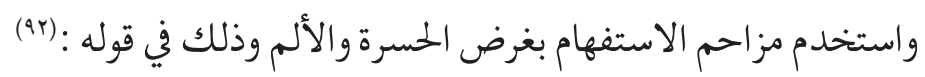

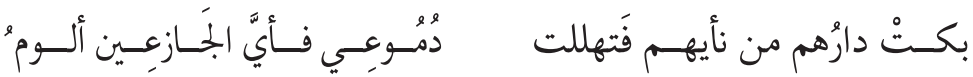

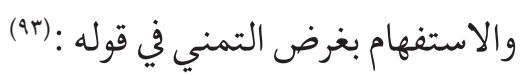

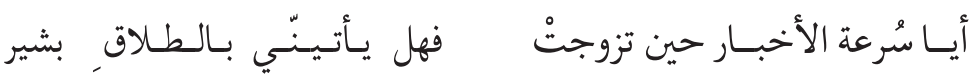

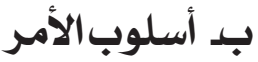

(فالامر هو طلب الفِعل من الأعلى إلى الأدنى حقيقة أو دعاء أي سواء أكان الطالب أعلى

في واقع الأمر ،أم مدعياً لذلك).. (94) الأعلى

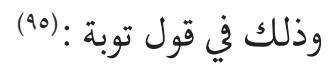

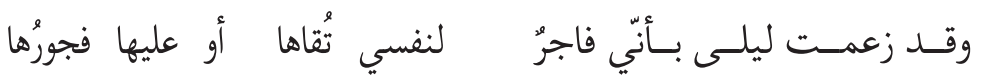

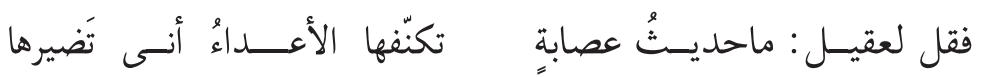

فالأمر في قوله (فقل لعقيل ) هنا غرضه التهديد . لماند

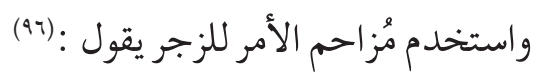

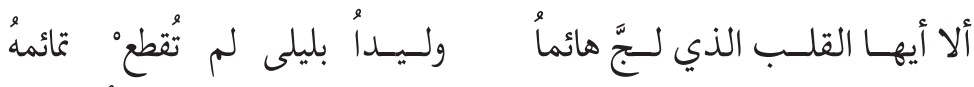

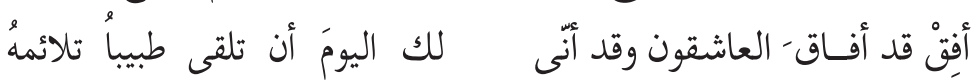

فهو يزجر قلبه عن عشق ليلى بقوله (أفق قد أفاق العاشقون )

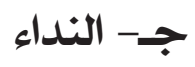

(وهو طلب المنادى بأحد أحرف المنادى الثمانية)(av)

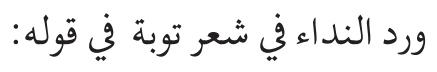

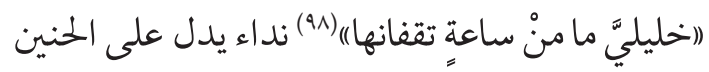




$$
\begin{aligned}
& \text { (انحليليَّ قد عمَّ الأسى وتقاسمت)|(99) نداء يدل على الحزن والأسى } \\
& \text { فحذف أداة النداء يا وذلك لقرب أصحابه من قلبه. } \\
& \text { وفي قوله :(ألا ياصفيَّ النفس كيف تنولها)(...) }
\end{aligned}
$$

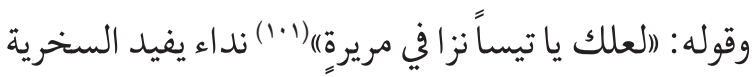

$$
\begin{aligned}
& \text { واستخدم مُزاحم النداء في قوله : }
\end{aligned}
$$

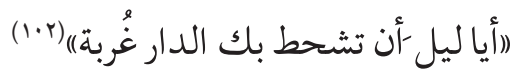

استخدم (الهمزة - يا)) ورخم ليلى (ليل) وذلك لقرب محبوبته من قلبه، واستخدم أداتين

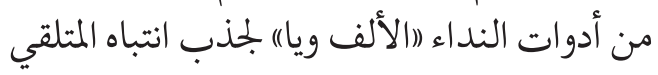

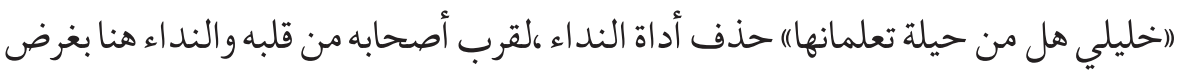
الاستغاثةبأصحابه.

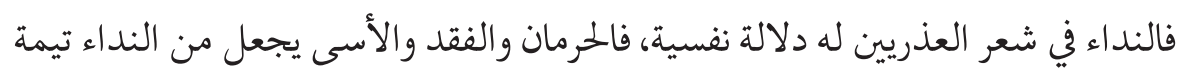

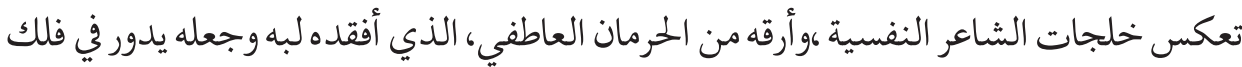

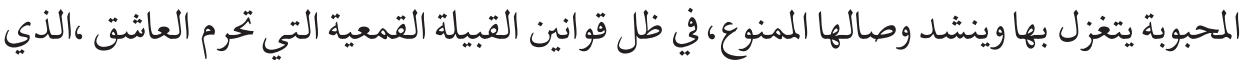

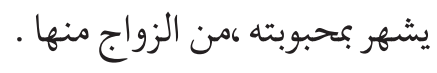

$$
\text { التتكرار }
$$

((فن قولي من الأساليب المعروفة عند العرب ،بل هو من محاسن الفصاحة)|(r.1)

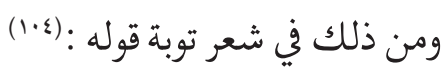

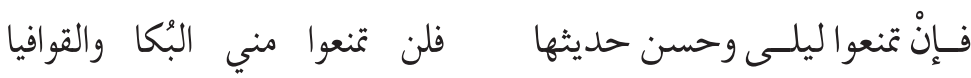

$$
\text { وقوله:(1.0) }
$$

فهـلا منعتــم إذمنعتـم كلامهــا خيالا يوافيني على النأي هادياً

$$
\text { وقوله :(1.7) }
$$

لــو أنَّ الهـوى عـن حسب ليلى أطعتُ، ولكنّ الهوى قد عصانيا

$$
\text { وقوله :(1.v) }
$$

$$
\begin{aligned}
& \text { وبي من هوى ليلى هوى لو أبثه } \\
& \text { وفي قول مُزاحم (1•) }
\end{aligned}
$$




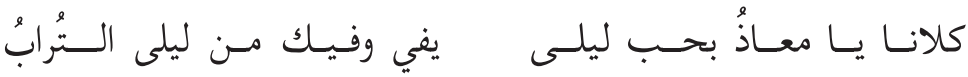

$$
\text { وقوله:(1.9) }
$$

أبينـي لنـا ياجدو يابنــت مالك أبيني فقد يعيا اللبيب فيسأل

$$
\text { وقوله:(11.) }
$$

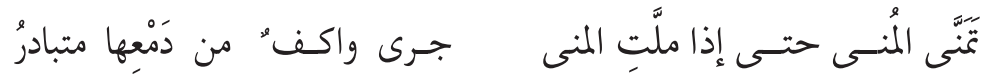

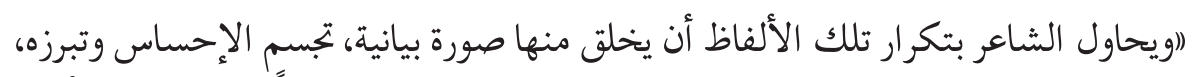

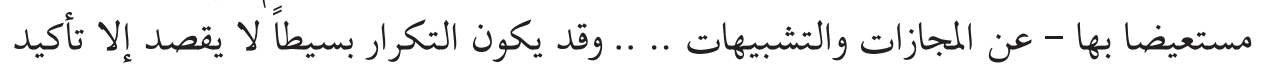
الانفعال أو الاستمتاع بترديد اسم حبيب أو مكان أو ذكرى ..(111)

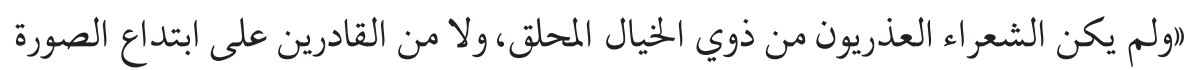

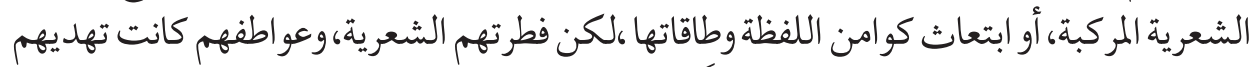

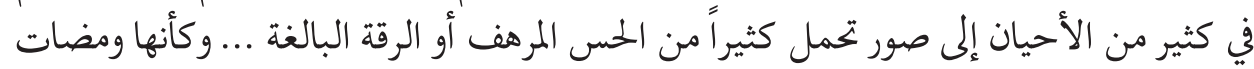

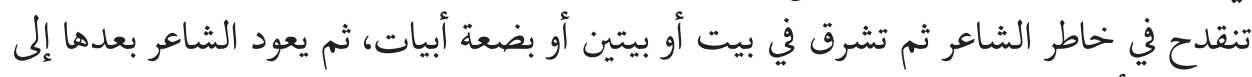

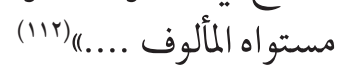

$$
\text { ونجد ذلك في التضمين (rا (I) عند مُزاحم }
$$

فيرسم الشاعر لنا صورة جزئية ،تبدأ في البيت التاسع والعشرين وتنتهي في السادس والثلاثين.

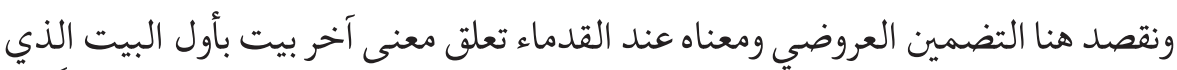

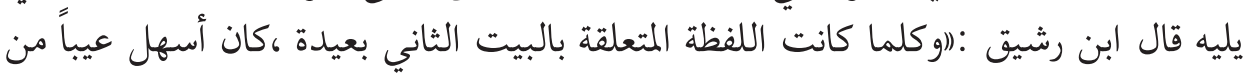

$$
\text { التضمين ||(11) }
$$

وقد عد النقاد التضمين عيباً وذلك لايمانهم بوحدة البيت

$$
\text { ومن ذلك قول مُزاحم في قصيدته البائية (110) }
$$

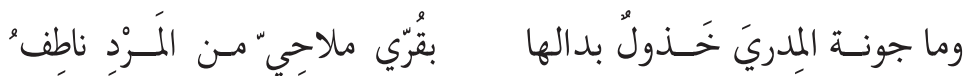

$$
\text { إلى قوله }
$$

بأحسن من جدوى ولا ضوء مزنة تــلألأ في داني الربـابـة صائفن

$$
\text { وقوله : (117) }
$$

وما أمُّم مكحولِ المدامع, طالعت 
بأحسن من جدوى مناط-قلادةٍ

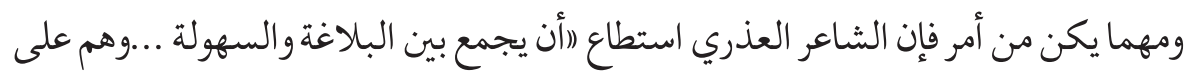

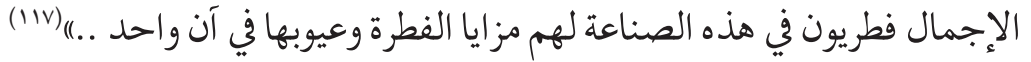

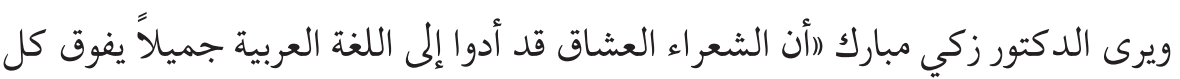

$$
\text { جميل ..بقوة الإفصاح من سر ائرها الوجدانية)(11) }
$$

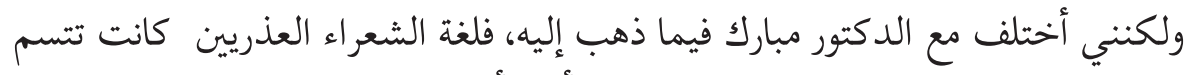

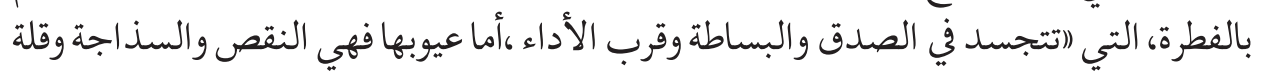

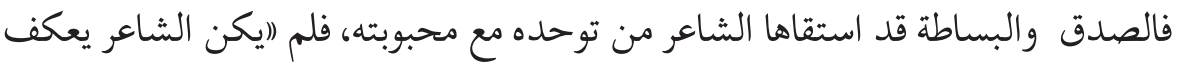

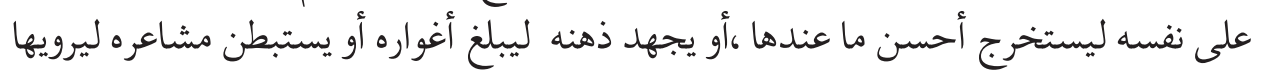

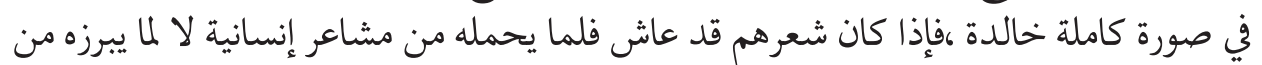

خصائص فنية)(1r.)

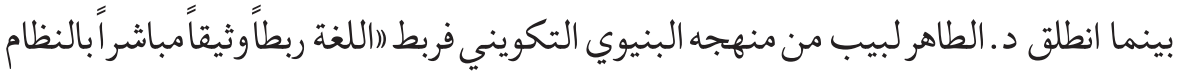

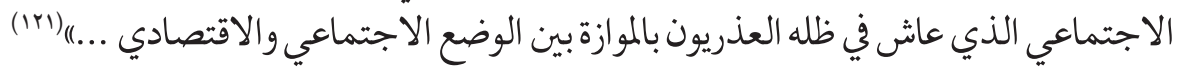

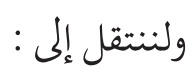

\section{بناء القصيدة والمقطوعت}

حفل ديوان توبة بالقصائد الطوال مثل قصيدته الهائية ،والتي بلغت خمسين بيتئاً تلتيها

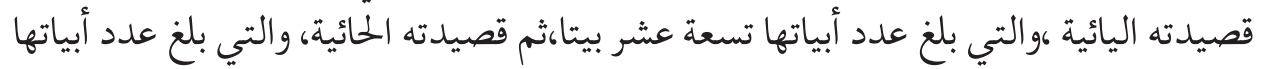

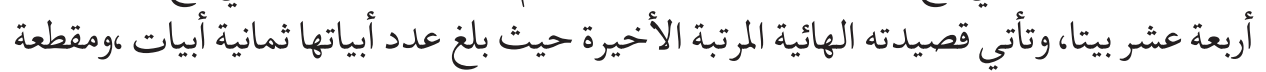

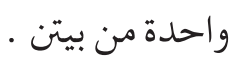

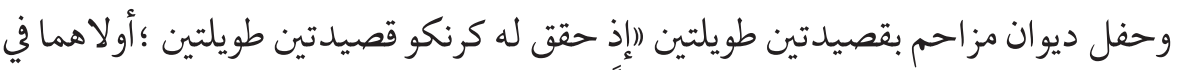
مائة وعشرة أبيات .والأخرى في ثلاثة وستين بيتاً)( Irr) وهذا الجمدول يوضح نسبة القصائد للمقطوعات والبحور 


\begin{tabular}{|c|c|c|c|c|c|c|}
\hline اسم المحبوبة & عدد الأبيات & البحر & المقطوعات & القصائد & |الصفحةبالديوان & الشاعر \\
\hline ليلى & 0. & الطويل & & الهائية & rI & توْبة بن الحُمير \\
\hline ليلى & $\wedge$ & الطويل & & الهائية & $\varepsilon \varepsilon$ & \\
\hline ليلى & 19 & الطويل & & اليائية & $\varepsilon V$ & \\
\hline ليلى & r & الطويل & الحائية & & 00 & \\
\hline ليلى & r & الوافر & البائية & & $9 \mathrm{~V}$ & مُزْاحم العُقيلي \\
\hline ليلى & 1. & الطويل & & الر ائية & 1.1 & \\
\hline جدوى & $1 \cdot \varepsilon$ & الطويل & & الفائية & $1 \cdot r$ & \\
\hline جدوى & ro & الطويل & & القافية & 11. & \\
\hline ليلى & 11 & الطويل & & الهائية & Irr & \\
\hline صفراء ، جدوى & Vr & الطويل & & الميمية & IrE & \\
\hline ليلى & $r$ & الطويل & الهائية & & IrA & \\
\hline ليلى & 0 & الطويل & الهائية & & Ir. & \\
\hline \multirow[t]{4}{*}{ مية } & $r$ & الطويل & اليائية & & $|r|$ & \\
\hline & & 1 & المقطوعات & $r$ & عدد القصائد & توْبة بن الحُمير \\
\hline & & $\varepsilon$ & المقطوعات & 。 & عدد القصائد & مُزْاحم العُقيلي \\
\hline & & 0 & & $\wedge$ & & المجموع الكلي \\
\hline
\end{tabular}

من الجدول السابق نجد أن النسبة بين القصائد والمقطوعات الغزلية في ديوان توبة جاءت كالتالي :

عدد القصائد الغزلية بالديوان =عدد القصائد بـعدد القصائد والمقطعات بالديوان

$$
\% v^{\circ}=1 \cdots \times r
$$

بينما نسبة المقطوعات جاءت كالتالي

عدد المقطوعات الغزلية بالديوان بجعدد القصائد و المقطوعات بالديوان

$$
\% \text { Y. }=1 \cdots \times 1 \%
$$$$
\text { القصائد : المقطوعات }
$$

$$
\text { \%० : } \% \text { Vo }
$$

بينما جاءت القصائد الغزلية والمقطوعات لمُزاحم العُقيلي على النحو التالي :

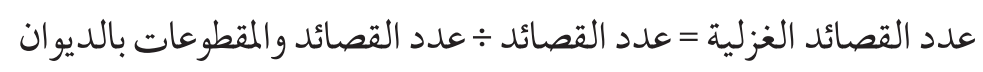




$$
\begin{aligned}
& \text { عدد القصائد = }
\end{aligned}
$$

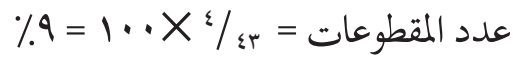

$$
\begin{aligned}
& \text { القصائد : : : : المقطوعات } \\
& \% \text { : } \% \text { : }
\end{aligned}
$$

\begin{tabular}{|c|c|c|c|c|}
\hline p & النسبة المئوية & المقطوعات & القصائد & الشاعر \\
\hline$\%$ & $\%$ \% , & 1 & $r$ & توبْبة بن الحَمير \\
\hline$\% \wedge$ & $T r, 0$ & $\varepsilon$ & 0 & مُزْاحم العُققيلى \\
\hline
\end{tabular}

وبعمل استقصاء احصائي للنسبة المئوية للقصائد والمقطوعات الغزلية لتُوبة ومُزاحم نجد أن

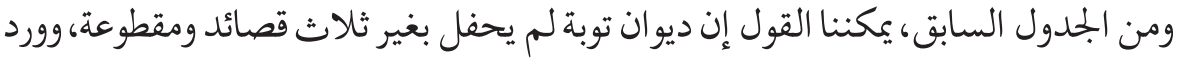

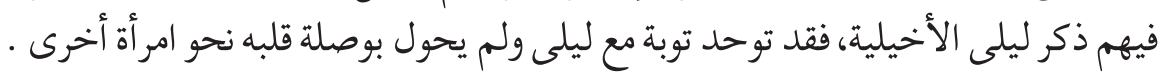

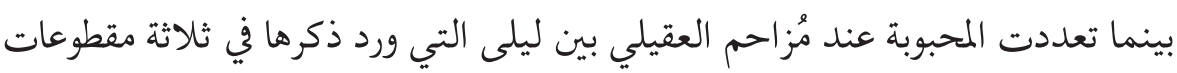

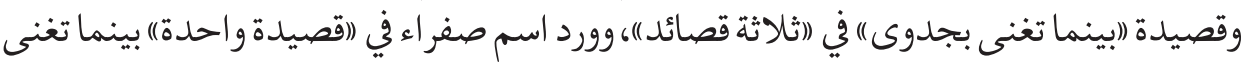

$$
\text { بميَّة في (مقطوعة واحدة)). }
$$

كما جاءت القصائد والمقطوعات عند كل من توبة ومزاحم على بحر الطويل، عدا مقطوعة

$$
\text { لمزاحم جاءت على بحر الوافر. }
$$

والسؤال الذي يطرح نفسه الآن ،لماذا جاءت معظم القصائد والمقطوعات على وزن بحر

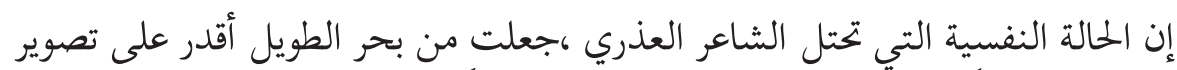

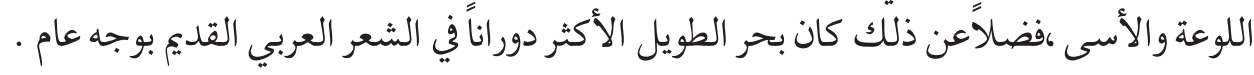

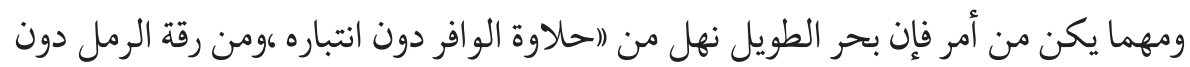

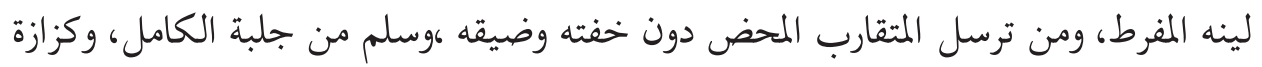

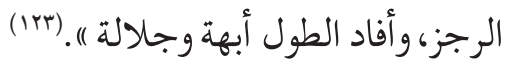

وهذا يتنافى مع ماجاء به أدونيس من أن الغزل العذري (اقد تجاوز بنية القصيدة القديمة إلى الى

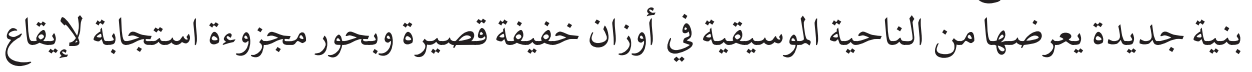
الحياة). (1r\& )

فضلا عن ذلك فإن القصائد والمقطوعات الغزلية العذرية، تمثل ترجمة لأحاسيس مجردة عن

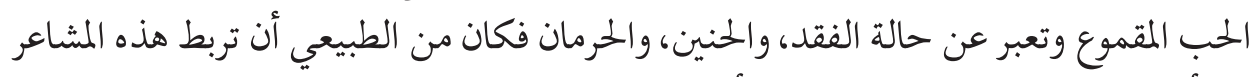

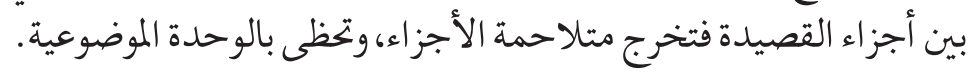


كما جاءت لغة هذا الشعر سلسة بعيدة عن الغريب، (احتى كاد شعرهم يخلو منه إلا حين

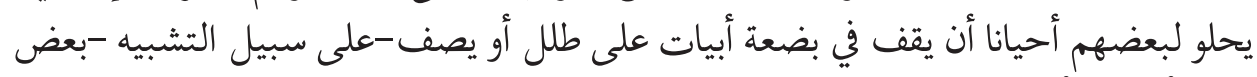

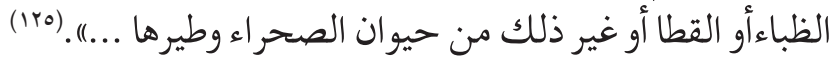

ومجمل القول إن سمات العامة للحب العذري يمننا أن نجملها في النقاط التالية : - بساطة المعنى، ومباشرتها ،وعدم الغموض والتعقيد ،والإغراق في الغريب. - غلب الصدق الفني على الشعر العذري.

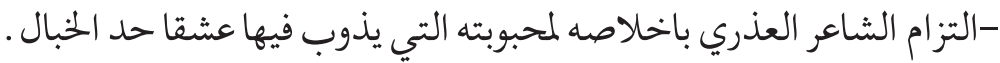

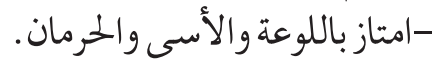
- ناقش المعاناة من الرقباء والوشاة. - الشعر العذري لم يكن وليد العصر الأموي ،بل يعد الامتداد الفعلي لشعر المتيمين

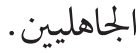
- تميزت لغة الشعر العذري بالسهولة والعذوبة .

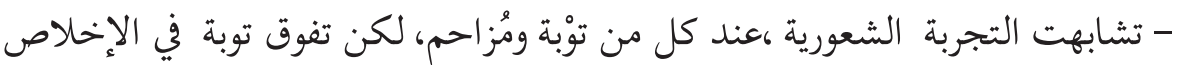

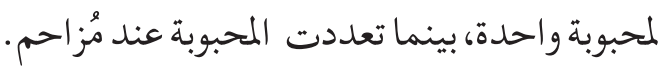
- اتسمت القصائد والمقطوعات بالوحات بلمدة الموضوعية.

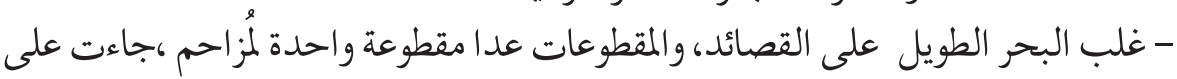
بحر الوافر.

- تماهت الموسيقى الخارجية مع الحالة الشعورية.

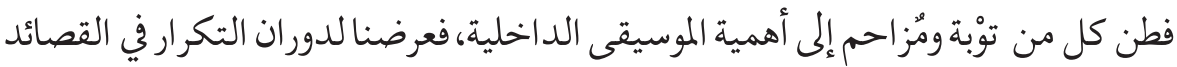
والمقطوعات، وذلك لترجمة مشاعر الفقد والحرمان.

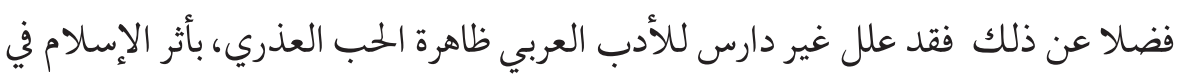

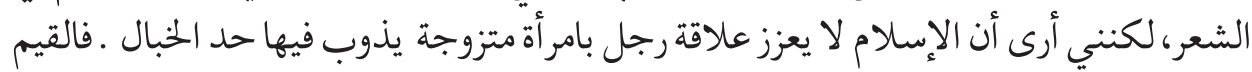

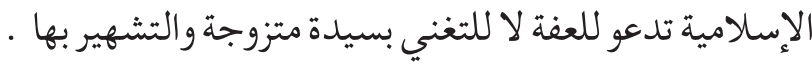

\section{الشعر العذري بمثابة علسة لاقطة}

تعكس الخشونة ،وشظف العيش في البادية، لذلك ترددت تيمة الحرمان في شعرهم، ويمكن

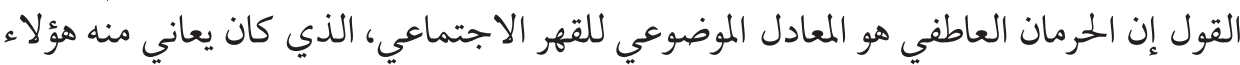

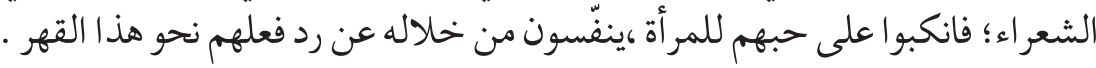




\section{هوامش البحث}

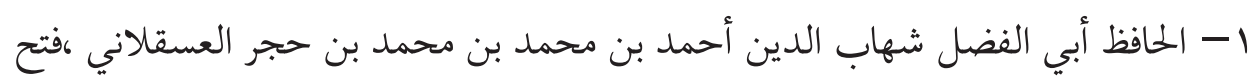

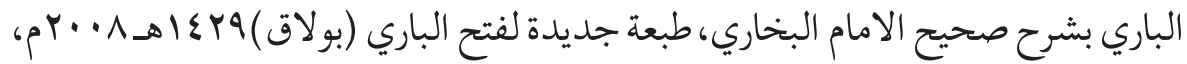

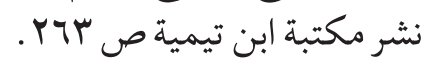

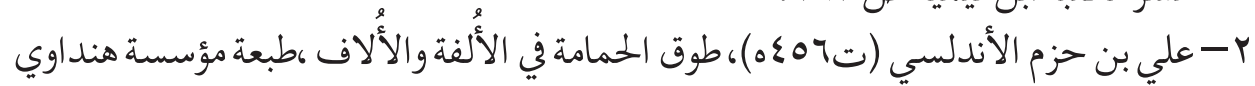

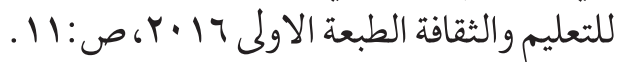

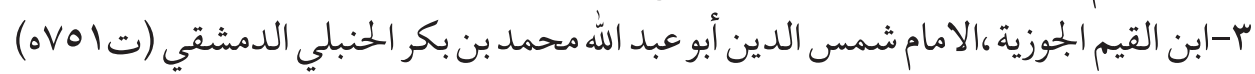

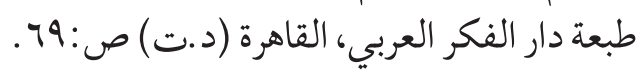

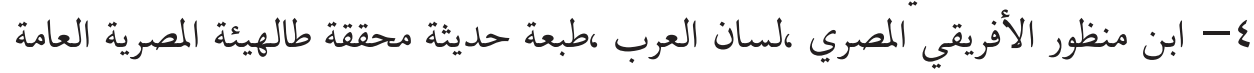

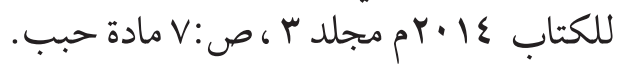

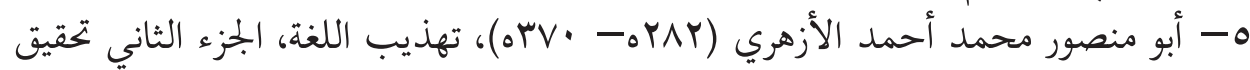

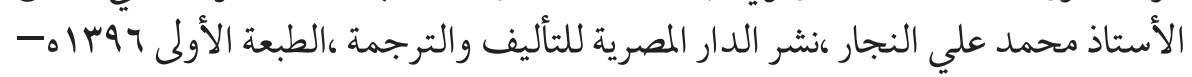

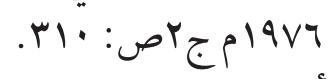

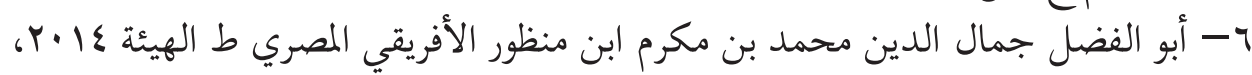

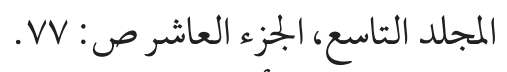

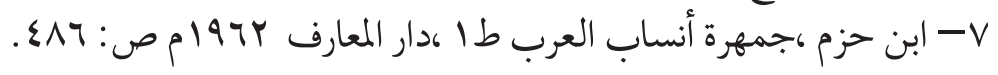

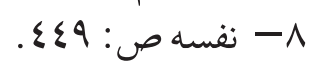

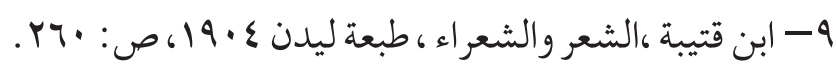

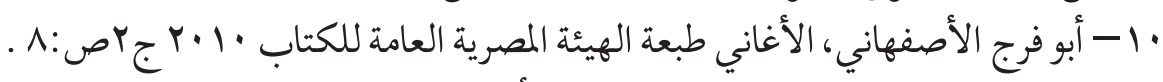

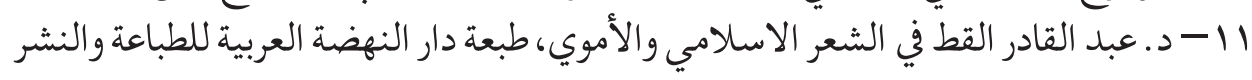

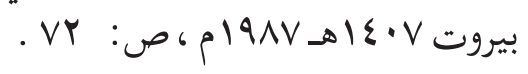

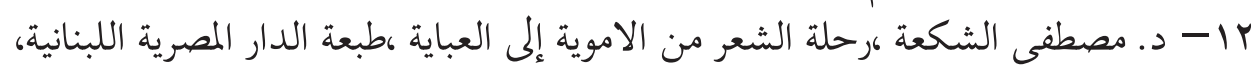

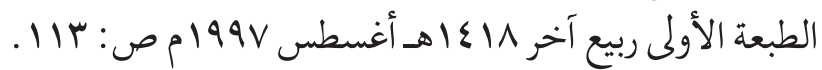

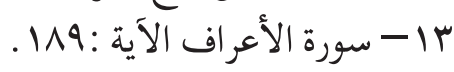

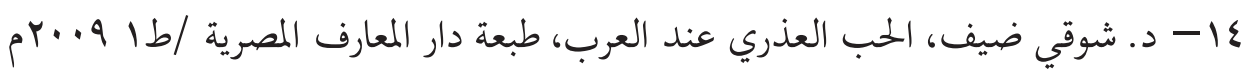

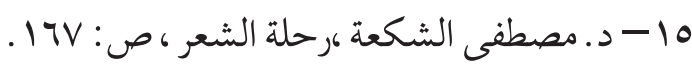

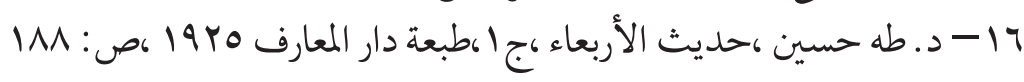

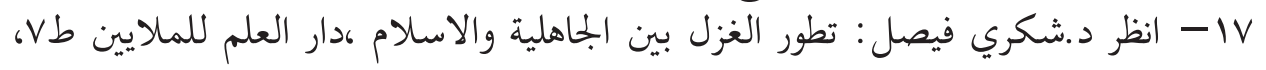

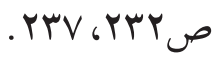


11 - د.شوقي ضيف تاريخ الادب العربي في الشعر الاسلامي الكتاب الثاني في عصر بني أمية

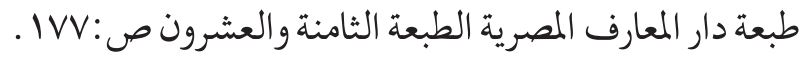

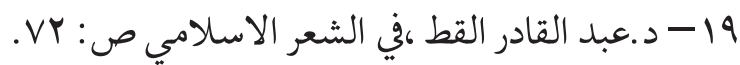

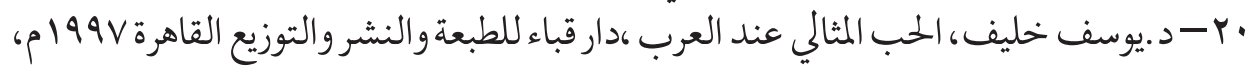
ص: $4 \cdot{ }^{\prime}$

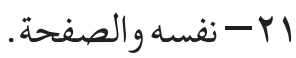

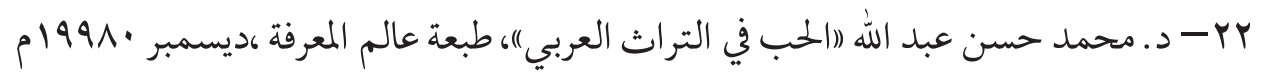
rro: r T - يوسف بكار:اتجاهات الغزل العذري في القرن الثاني الهجري ،طبعة دار المناهل للطباعة

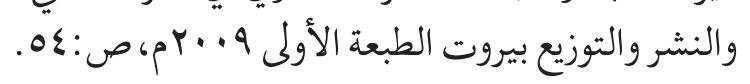

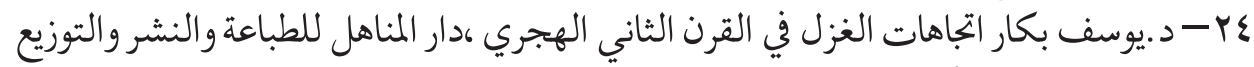

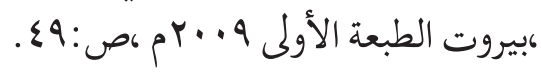

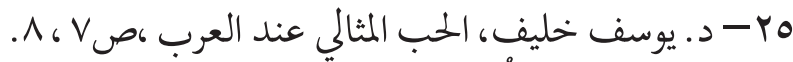

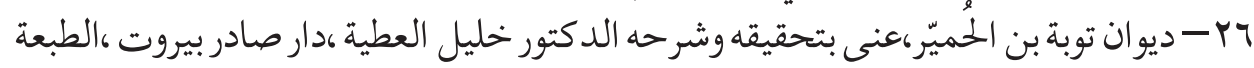

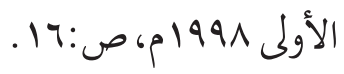

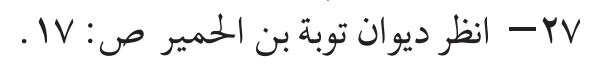

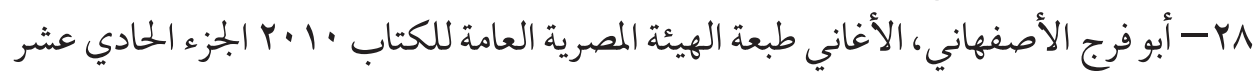
ص:

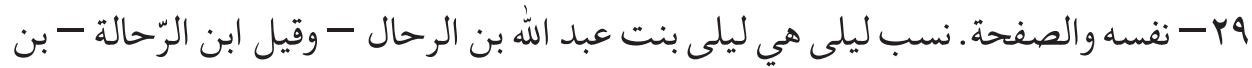

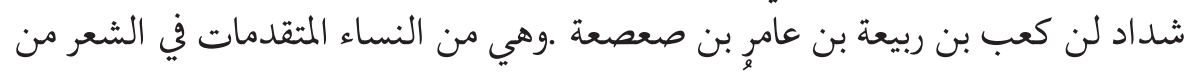

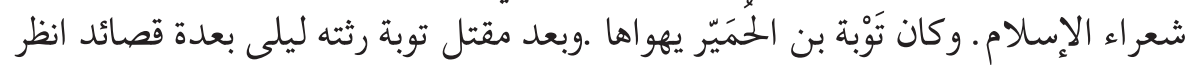

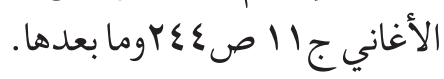

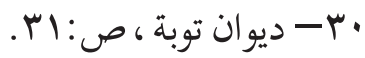
اب- النّوى والنية: الوجه الذي تقصده ،يقال : نأيته هونائتُعنه :يقال :استمر مريره :أي نضا

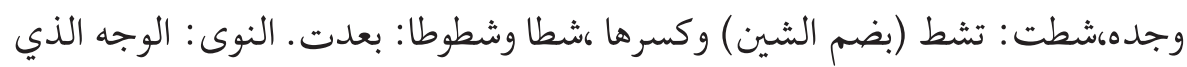

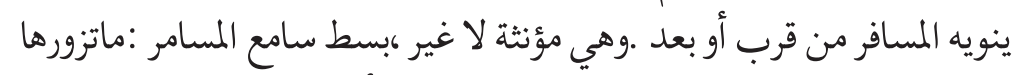

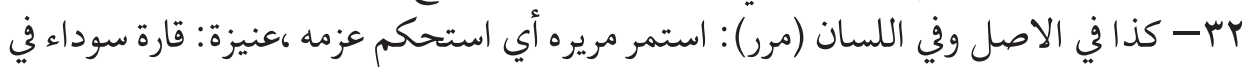

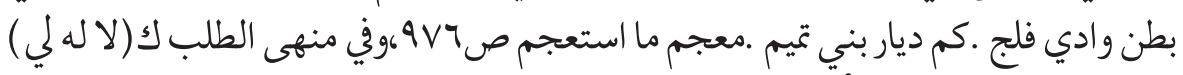

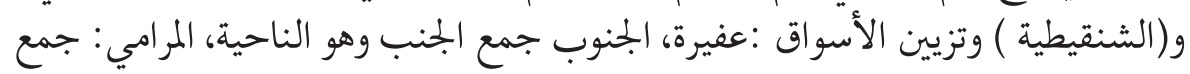

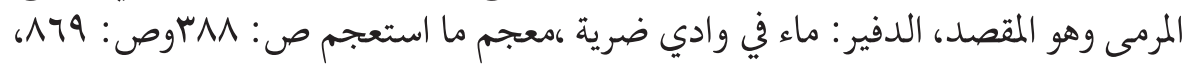

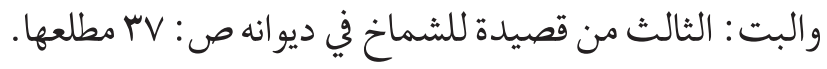




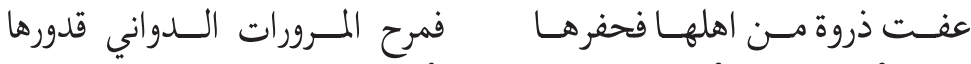

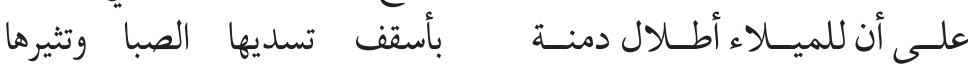

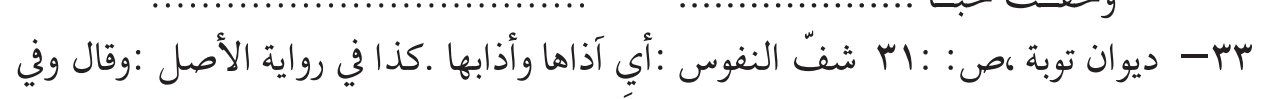

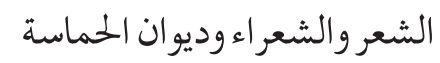
وأشعار النساءو آمالي القالي ومصارع العشاق والحماسة البصرية وذم الهوى وبسط = سامع

$$
\text { المسامر: يقول }
$$

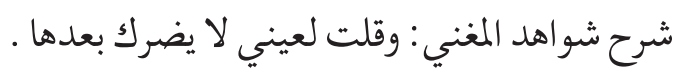

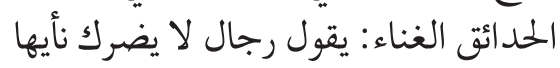

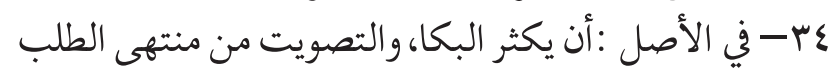

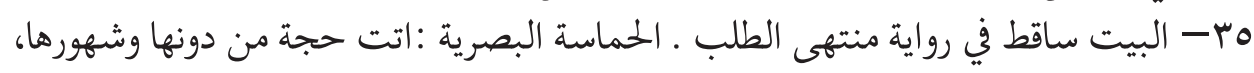

ديوان توبة ص:بك

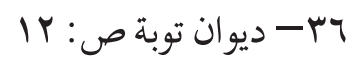

Tr

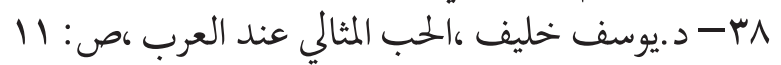

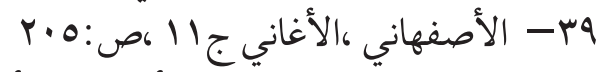

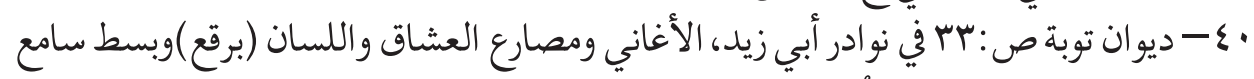

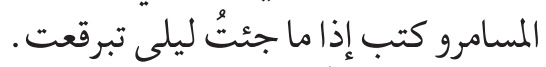

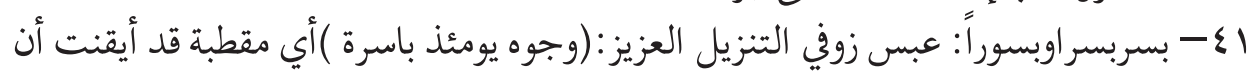
العذاب نازل بها تزيين الأسواق : عن حاجتي وقصورها .

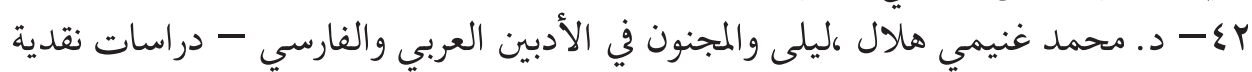

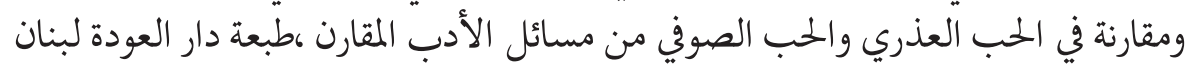
rr: r

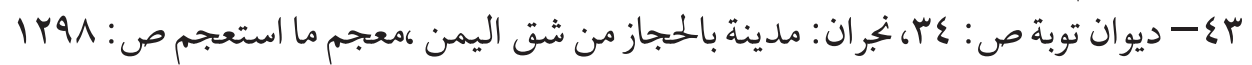

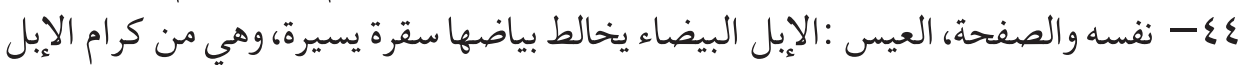

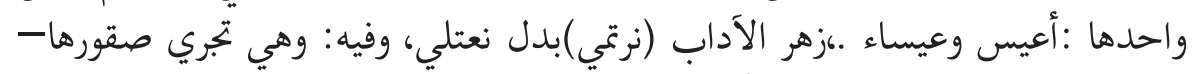

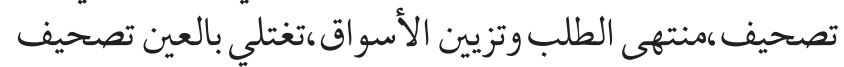

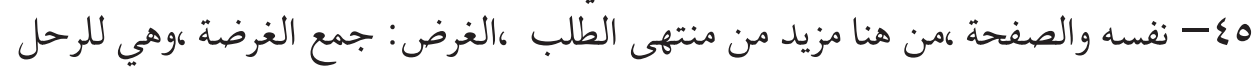
كالخزام للسرج 
جـ - نفسه والصفحة، الأغاني وتجريد الأغاني: بالقوز اليفاع، القوز: بالفتح العالي من الرمل كأنه

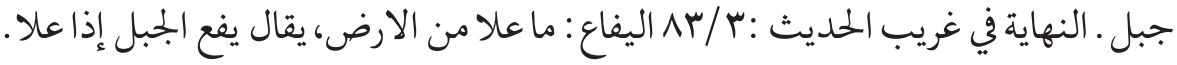

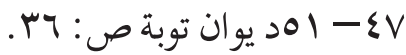

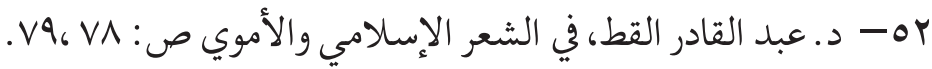
rه- ديوان توبة ص: §؟. سرائره :سرائر الفؤاد ، ولوع بالفتح، يقال : أولع بذلك إيلاعاً .يقول : ولكنني إذا عُلّقها لم أصبر يعني فؤاده.

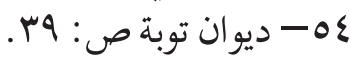
(*) البدن: جمع بدنة وهي ناقة أو بقرة تساق فتذبح بنى.

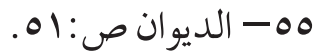

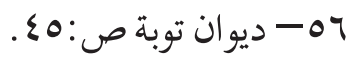

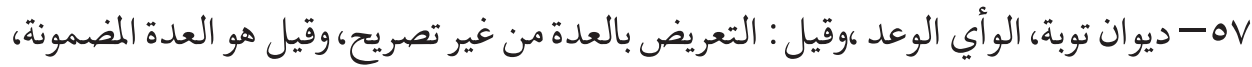

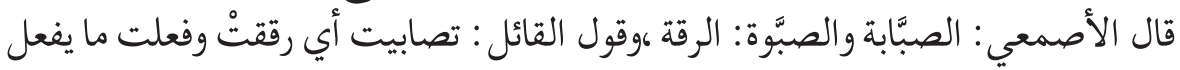

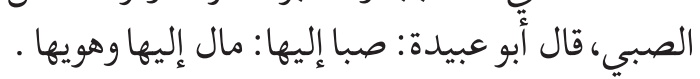

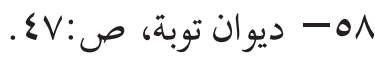

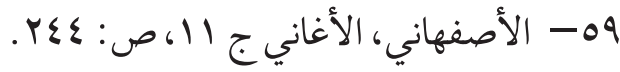

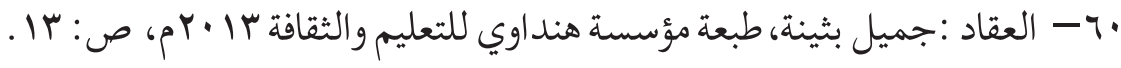

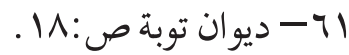

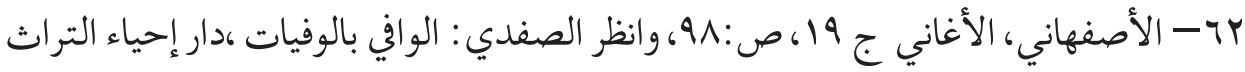

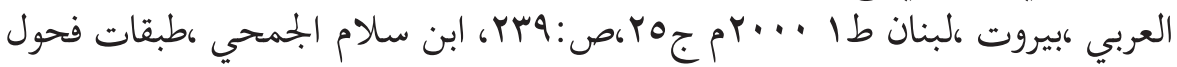

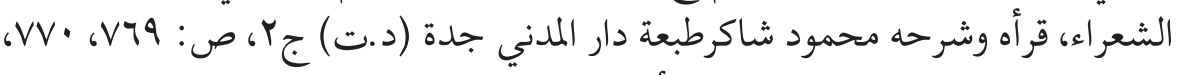

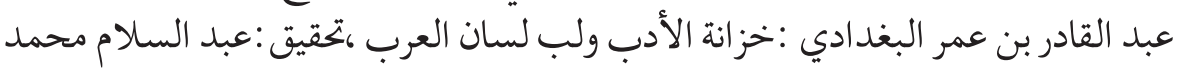

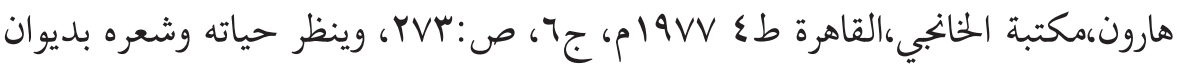

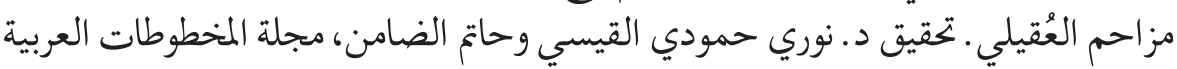

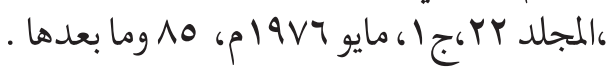
rا

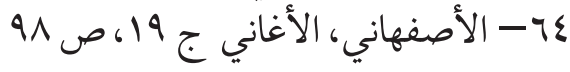

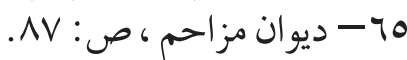

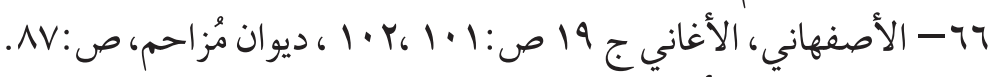
N

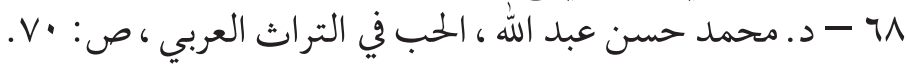




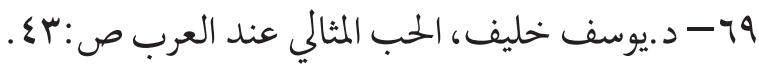

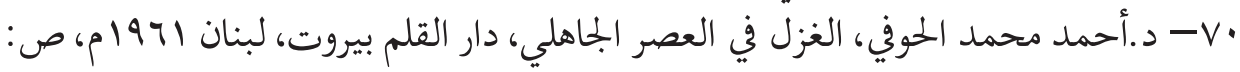
.rI乏

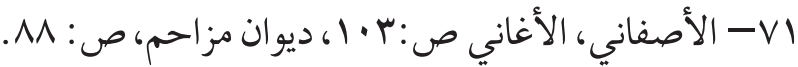

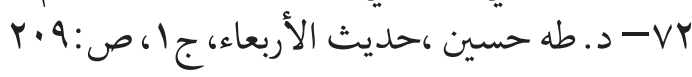

$$
\begin{aligned}
& \text { Q } \\
& \text { 酒 } \\
& \text {-V } \\
& \text { TI -VT } \\
& \text { - نفسه ص:VV } \\
& \text { - نفسه ص:VA }
\end{aligned}
$$

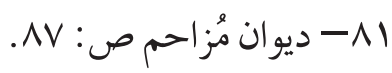

$$
\begin{aligned}
& \text { r r }
\end{aligned}
$$

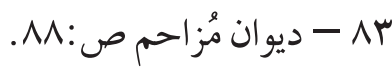

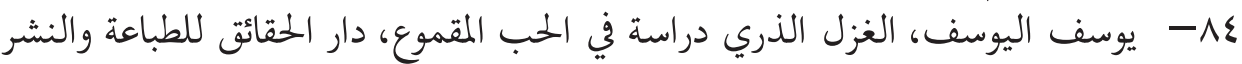

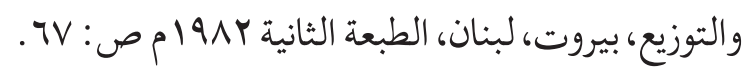

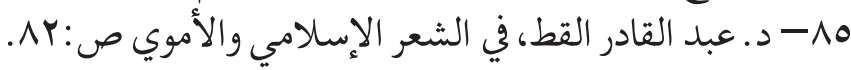

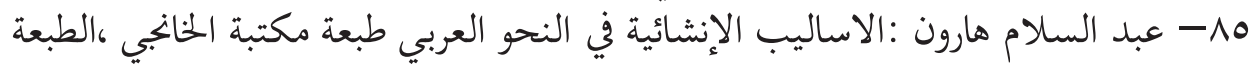

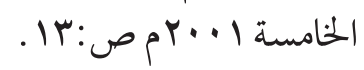
T1 - عبد المتعال الصعيدي، بغية الإيضاح في تلخيص المفتاح، طبعة مكتبة الآداب، 1999م،

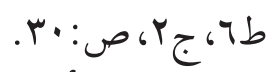

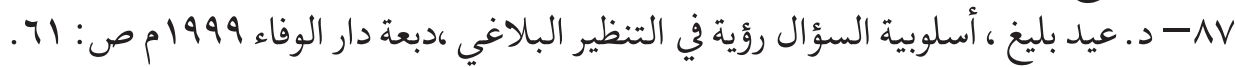

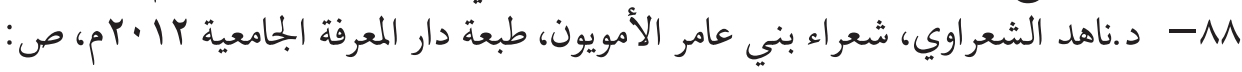
ror

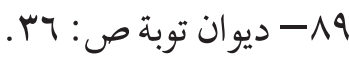

$$
\begin{aligned}
& \text {. }
\end{aligned}
$$

| I

ا

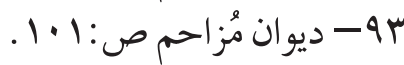

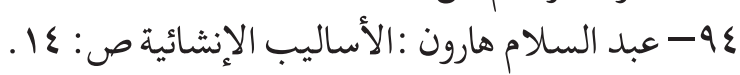

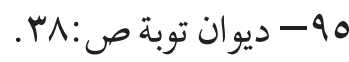




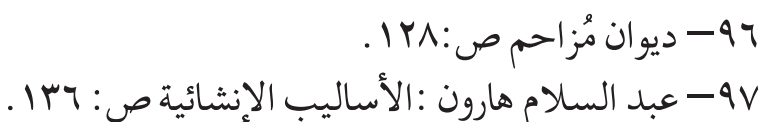
M

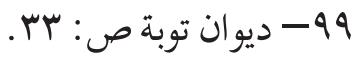

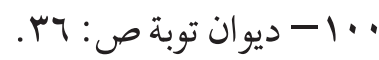

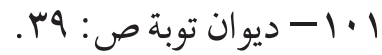

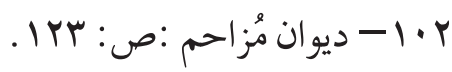

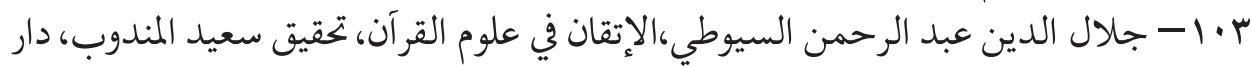

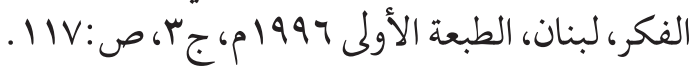

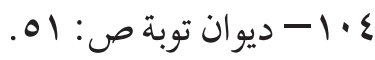

$$
\begin{aligned}
& 0 \text { • } 1 \text { - نفسه والصفحة. }
\end{aligned}
$$

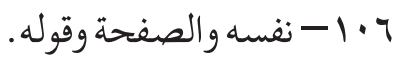

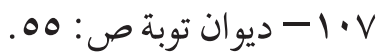

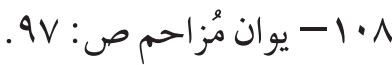

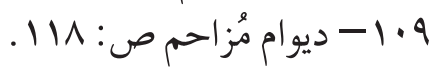

$$
\begin{aligned}
& \text {. 11- نفسه ص: ب. 11. }
\end{aligned}
$$

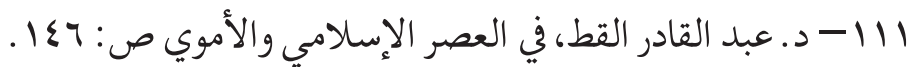

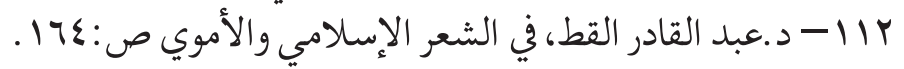

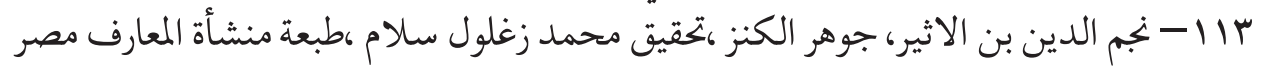

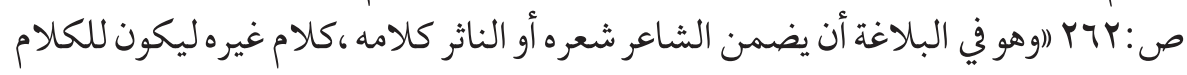
طلاوة وحلاوة بالتضمين").

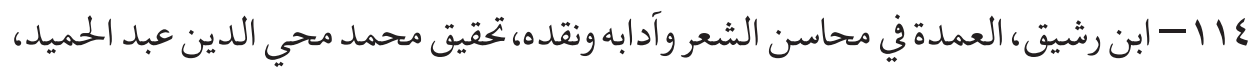

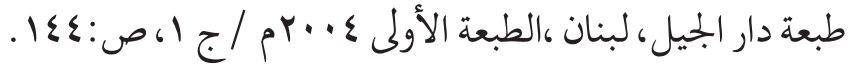

$$
\begin{aligned}
& \text { 110 - } 110 \\
& \text { 11 } 117 \\
& \text { IIV }
\end{aligned}
$$

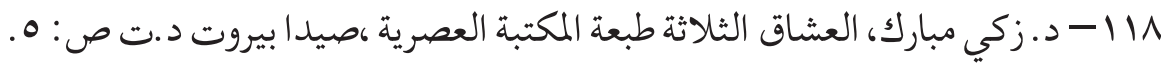
ا 119 • 1 ا - د. حسين نصار ،قيس ولبنى شعر ودراسة وتحقيق، الناشر : مكتبة مصر دار مصر للطباعة .01: (1971 
|r| - ينظر د. الطاهر لبيب، سوسيولوجيا الغزل العذري، ترجمة مصطفى المسناوي، طبعة دار

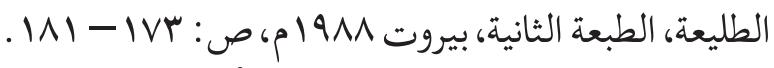

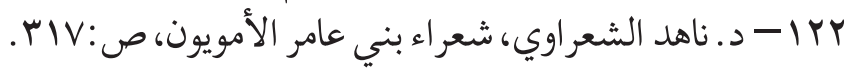

